
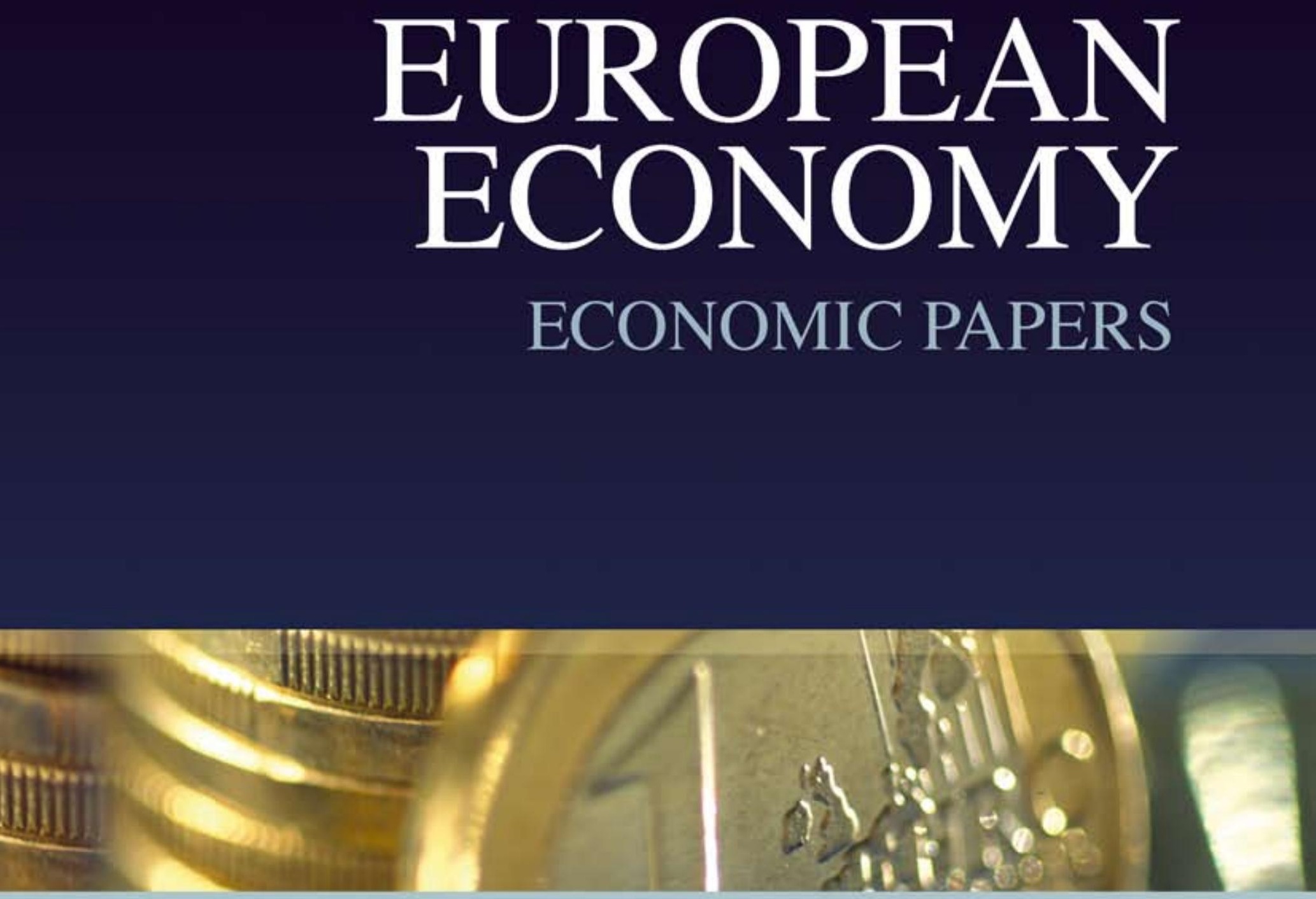

Number 281 - June 2007

Nominal and real wage flexibility in EMU

by Alfonso Arpaia

(Directorate-General for Economic and Financial Affairs) and Karl Pichelmann

(Directorate-General for Economic and Financial Affairs, Associate Professor, Institute d'Etudes Européennes,

Université Libre de Bruxelles) 
Economic Papers are written by the Staff of the Directorate-General for Economic and Financial Affairs, or by experts working in association with them. The "Papers" are intended to increase awareness of the technical work being done by the staff and to seek comments and suggestions for further analyses. Views expressed represent exclusively the positions of the author and do not necessarily correspond to those of the European Commission. Comments and enquiries should be addressed to the:

\section{European Commission}

Directorate-General for Economic and Financial Affairs

Publications

BU-1

B - 1049 Brussels, Belgium

ECFIN.E3/REP/2363

ISSN 1725-3187

CEuropean Communities, 2007 


\title{
Nominal and real wage flexibility in EMU
}

\author{
Alfonso Arpaia ${ }^{+}$ \\ Karl Pichelmann *
}

\begin{abstract}
Both common macroeconomic shocks and country-specific developments have subjected the flexibility of wage setting mechanisms in the euro area to a stress test in recent years. Against this background, this paper takes a fresh look at wage flexibility in EMU and attempts to draw a few lessons from the experience of the early years. First, we set the stage for the analysis by providing a brief description of the stylised facts regarding nominal and real wage and unit labour cost developments in the euro area over the recent business cycle. Then, the paper presents an empirical assessment of wage inertia based on new econometric estimates of a Phillips-curve type wage equation across euro area countries and offers an interpretation of the main findings with respect to nominal and real wage flexibility. Finally, we investigate the cyclical responsiveness of relative competitive positions among euro area countries. We conclude that from a bird's eye perspective euro area wage and labour cost dynamics have been quite benign in the past couple of years. However, our estimates suggest that persistent cross-country differences in wage and labour cost developments have not always reflected warranted adjustment needs; they are rather indicative of an eventually insufficient degree of nominal and real wage flexibility in the euro area.
\end{abstract}

JEL-Code: E24, J30, J50

+ EU Commission, Directorate General for Economic and Financial Affairs.

* EU Commission, Directorate General for Economic and Financial Affairs, and Associate Professor, Institute d'Etudes Européennes, Université Libre de Bruxelles. 


\section{Introduction ${ }^{1}$}

Recent years have seen some improvement in overall labour market performance in the euro area, as indicated by rising employment rates, a trend increase in participation and a fall in structural unemployment. It has proven hard to explain these developments without taking recourse to relatively widespread wage moderation observed for the euro area as a whole in the past couple of years. However, from a more sceptical perspective, over the recent protracted period of sluggish economic activity wage flexibility appears to have provided little, if any, support for cyclical recovery; thus, present wage rigidities may have seriously hampered the smooth adjustment to the macroeconomic shocks that have hit the euro area in recent years. Similarly, persistent cross-country differences in wage and labour cost developments, which may not always have reflected warranted intra-country adjustment needs, are indicative of an eventually insufficient degree of wage flexibility in the euro area.

These observations also square with predictions that the formation of EMU and its associated impact on wage bargaining behaviour could affect both the level of (un-) employment and the flexibility by which wages adjust to shocks. It has been widely held that, in general, EMU should provide improved framework conditions for employment-compatible wage bargaining; indeed, with all the elements of the Marshall-Hicks rule of labour demand likely to operate, the link between wage and employment trends becomes more evident and stringent. However, it has also been argued that inherent in the integration process are forces such as stronger wage interdependencies which tend to make wages less flexible; thus, more protracted output adjustment may follow, even though the equilibrium level of employment may increase and structural unemployment be lower.

Inflexibility of wages may be more costly in EMU than before in terms of employment. For example, a higher degree of competition, which stems from higher price transparency, increases the responsiveness of employment to real wages. In case of adverse shocks, rigid wages would lead to higher unemployment.

Real or nominal wage flexibility can be seen as the speed with which real or nominal wages adjust to real or nominal shocks. However, the nature of the shock is not the main source of the real or nominal wages' rigidities. By interacting with these rigidities, nominal and real shocks determine the distribution of the changes of prices and quantities in response to unexpected changes in price or technological shocks (see Bruno and Sachs, 1985; or Blanchard, 2006). For example, the failure of expected real bargained wages to adjust to productivity or unemployment shocks triggers and adjustment mechanism which influences the nominal wage inflation. In Blanchard and Katz (1999), the extent to which the real expected wage is indexed to the past real wages is responsible for the stickiness of wage inflation.

The economic disturbance enforces a change of the wage rate and flexibility is a measure of the pace with which actual wages respond to changed market conditions. In the paper we look at three different concepts of nominal and real wage flexibility:

- The response of nominal wages to changes in the price level or inflation. The delay in the reaction of nominal wages to price changes determines the degree of nominal wage inertia. This is high when changes in current price or inflation, originating from real or nominal shocks, are only to a minor extent transferred on nominal wages in the same period. This form of flexibility has attracted some attention among economists because nominal wages are usually thought to be rigid when a downward adjustment is required. Hence, there is an

\footnotetext{
1 We are indebted to Mary McCarthy, Werner Roeger and Max Watson for helpful comments and suggestions. Of course, the usual disclaimer applies. In particular, the views expressed in this paper are strictly personal and do not necessarily reflect those of the EU Commission or its Services.
} 
asymmetry in the response of wages to changes in prices implying a stronger and sharper increase when inflation rises accompanied by only a slight change when inflation pressures redeem.

- The response of real wages to labour market conditions (i.e. either to changes in unemployment or in productivity) due to the presence of labour market frictions. Real wage flexibility is low when it takes time for a dis-equilibrium in the labour market to be eliminated. Similarly, a high degree of real rigidity entails a situation where real wages or mark-up of price over marginal costs respond little to demand pressures.

- The response of wages to changes in the composition of labour demand or labour supply. This relative wage flexibility is associated with geographical, sectoral and skill mismatch. Wage compression may inhibit the possibility that individual skills, individual productivity or geographical conditions are correctly reflected in relative wages. A similar mechanism is at work when there is a shift in consumers' preference from domestic to foreign produced goods. When this shock occurs, the adjustment in relative prices and wages is required to balance labour demand and labour supply. The adjustment may also occur via a change in the nominal exchange rate which may, eventually have feedbacks on the wage formation mechanism. As nominal exchange rates between euro-area countries no longer exist, intra-euro area real exchange rate adjustment can only come via changes in relative price and unit labour cost across countries, in particular changes in relative wages since productivity may be hard to influence in the short- to medium-term. Thus, flexible labour and product markets bring about a swift realignment of real effective exchange rates and correction of economic divergences. We will call the adjustment of domestic to foreign wages, relative wage flexibility.

Hence, two different dimensions of wage adjustment mechanisms need to be distinguished: (i) nominal wage and price flexibility is key in responding to country-specific aggregate demand shocks that alter real equilibrium exchange rates: flexible money wages, if combined with flexible prices, should impact on the cyclical sensitivity of output and employment, bringing about the required changes in real effective exchange rates and allowing for equilibrating current account dynamics. (ii) real wage flexibility to bring real wages in line with productivity developments at the regional, sectoral and occupational level; flexible real wages will allow for a smooth reallocation of labour resources across economic activities in the event of industryspecific or supply-side shocks, thus lowering equilibrium unemployment.

Against this background, this paper takes a fresh look at wage flexibility in EMU and attempts to draw a few lessons from the experience of the early years. The paper is organised as follows. Section 2 sets the stage for the analysis providing a brief description of the stylised facts regarding nominal and real wage and unit labour cost developments in the euro area over the recent business cycle. Section 3 presents an empirical assessment of wage inertia based on new econometric estimates of a Phillips-curve type wage equation across euro area countries and offers an interpretation of the main findings with respect to nominal and real wage flexibility. Section 4 investigates cyclical behaviour of prices and costs competitiveness indicators. Section 5 simply concludes.

\section{Wage and unit labour cost developments}

\subsection{The picture at the euro area aggregate level}

With price stability and a high degree of sustainable convergence being key requirements for adopting the euro, the run-up to EMU had seen impressive progress regarding nominal stabilisation in the euro area in terms of both prices and wages. Indeed, in the 1990s a remarkable 
disinflation process developed and the inflation rate had fallen below $2 \%$ by 1997 . While the lacklustre overall economic performance of the early years of EMU certainly contributed to a reduction in price and wage pressures, there can be little doubt that the high degree of nominal stability had been primarily the result of the systemic changes associated with the run-up to EMU.

Obviously, in the EMU framework, it is even more important than in the past for wage developments in each country to be in line with both the macroeconomic framework set at the Community level and the individual country-specific requirements in order to achieve the following goals:

(i) to achieve, overall, nominal wage developments consistent with the goal of price stability. Excessive nominal wage increases triggering inflationary risks for the euro-zone as whole - as will hold true, in particular, in the case of larger countries - will inevitably provoke a tightening of monetary conditions with adverse effects on growth and employment in the entire monetary union.

(ii) to avoid structural competitiveness loss at country level. While inflationary wage pressure may not significantly affect overall euro-area inflation when confined to one - smaller - country or region alone, it will sooner or later, via its effect on relative unit labour costs, depress competitiveness and employment in this country or region. Such a development, if confined to the short-term and representing the response to an asymmetric cyclical boom, may actually be part of the necessary intra-area adjustment process; however, a protracted structural loss of relative competitiveness needs to be avoided as its inevitable reversal could prove costly in terms of output and employment.

At the aggregate euro-area level, the sketched requirement translates into the well-known condition that average nominal unit labour cost growth should not jeopardize price stability (i.e. the inflation target as set by the ECB). The (non-)inflationary threshold for aggregate wage growth can then be approximated by the sum of trend productivity growth and the price stability target of the ECB of close to but below $2 \%$.

In recent years, both common macroeconomic shocks and country-specific developments have tested the flexibility of the wage formation mechanism in the euro area. For the euro area as a whole, the overall wage discipline has been preserved with no evident signs of second-round wage effects. Nominal wage growth per worker has been remarkably stable since the beginning of EMU. However, with nominal wage growth rather invariant to the cyclical situation, the slowdown in labour productivity growth translated into greater increases of nominal unit labour costs in 2001, 2002 and 2003, clearly exceeding the benchmark value consistent with the monetary policy goal to keep inflation close-to-but-below 2 per cent. More recently, though, the rebound in productivity growth kept nominal unit labour cost growth on the moderate path that characterises the second half of the 1990s and the early years of EMU (Graph 1). 


\section{Graph 1}

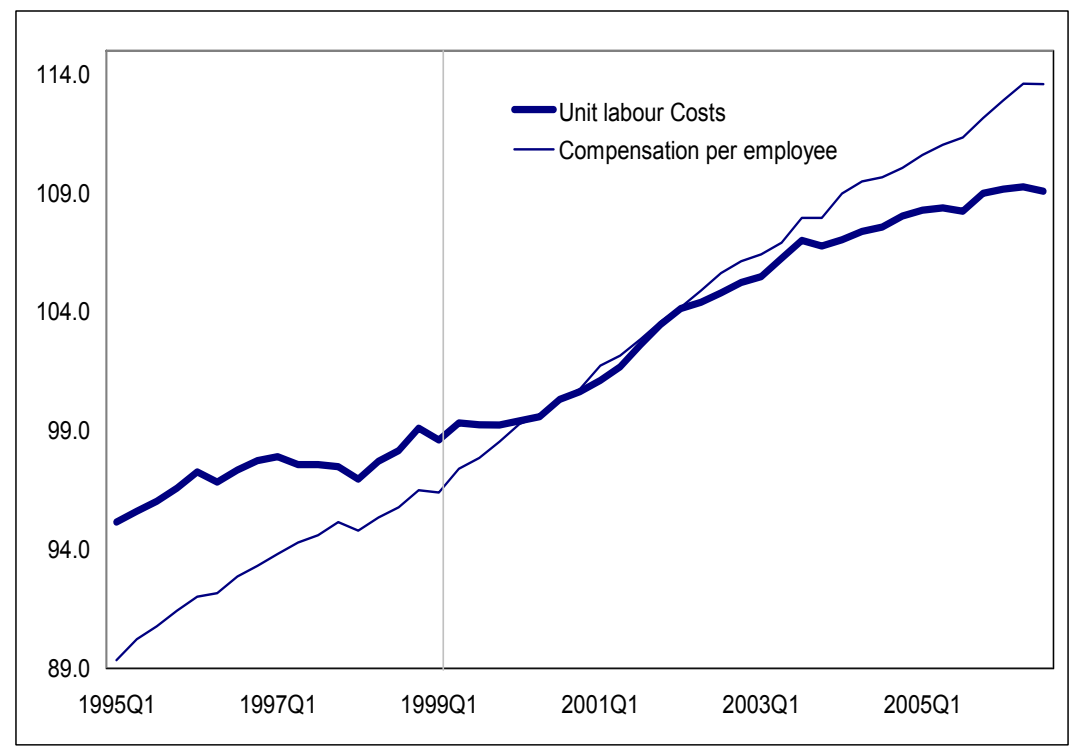

Source: National Accounts, Eurostat

Further evidence for overall wage discipline can be obtained from a look at the evolution of a real wage gap indicator that captures shifts in the aggregate wage-setting curve in the euro area (Blanchard, 1997, 1998). The indicator compares real wages with a measure of labour efficiency based on Harrod-neutral technical progress, thus computing a measure of real wages in efficiency units. Real product wages are augmented by a factor representing the wage dampening effect of a positive unemployment gap. More formally, the wage gap indicator is derived from a simple wage-setting equation relating the real product wage in efficiency units (w/e) to the unemployment rate $U R$ and a shift parameter $Z$ that captures other relevant labour market conditions affecting wage pressures in a $\log$-linear manner: $\log (w / e)=-b U R+Z$ with $b$ denoting the semi-elasticity of real efficiency wages with respect to unemployment. The real product wage $(w)$ is the gross nominal wage (including employers' contributions to social security) divided by the GDP deflator. The series for labour efficiency $(e)$ is derived under the assumption of Harrodneutral technical progress as the Solow residual divided by the labour share, reflecting the condition for labour productivity growth along the balanced growth path. A real wage gap indicator can then be constructed using $Z=\log (w / e)+b U R$, with $b$ set to 1 and, finally, normalising the series to equal zero in 1970.

The chart below gives the results for the evolution of the refined wage gap indicator for the EUR12 , assuming a value of one for the unemployment semi-elasticity of real wages. Overall the series shows a large increase in the wage gap indicator variable over the 1970s, with a peak of more than 10 per cent in the early $1980 \mathrm{~s}$; thereafter, wage pressure gradually abated, with the exception of the 1991-1994 period, when the wage gap started widen again despite unemployment still hovering around in the 8 percent range. The second half of the 1990s was characterised by a continued process of wage moderation resulting in a monotonic decline of the wage gap indicator. At present the real wage in efficiency units for the area as a whole has clearly fallen below its level in the beginning of the 1970s. Taking the increase of unemployment since then into account, in recent years the real wage gap indicator has stayed somewhat below its value thirty years ago. 


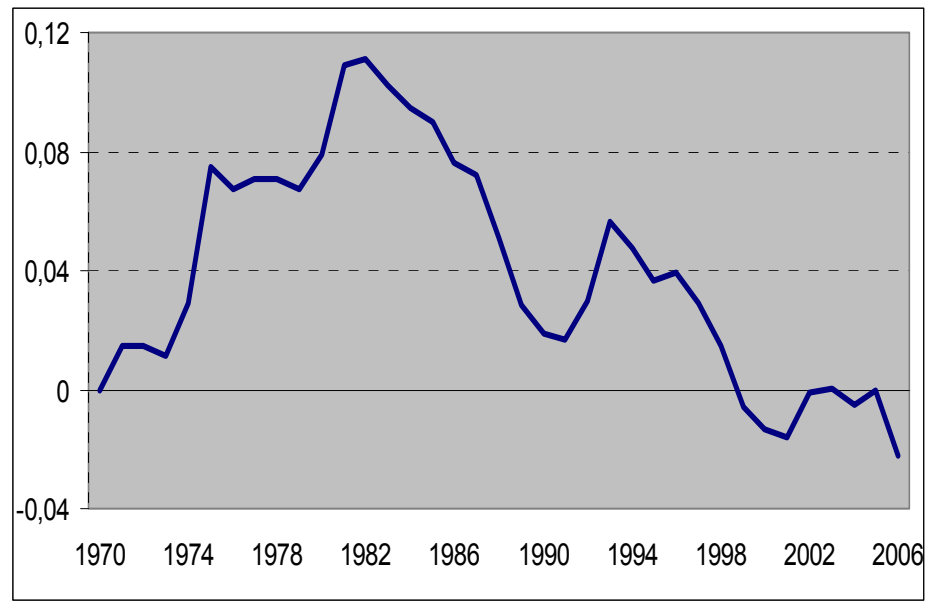

Source: authors' calculations

In summary, from a bird's eye perspective euro area wage and labour cost dynamics have been quite benign in the past couple of years and a risk assessment at the aggregate level does not point to any imminent danger for stability-conducive wage settlements. Nominal wage growth must be expected to accelerate in line with cyclical improvements, but some rebound in trend productivity growth, measures to increase labour supply availability and other structural factors should help to keep a lid on excessive wage claims.

\subsection{Intra-area developments in competitiveness}

The lack of wage costs pressures in the euro-area does not exclude that sizeable disequilibria in some countries have been built up since the inception of the monetary union. Differences in wage growth across Member States remain pronounced. The historically low rate of a $2.5 \%$ increase in nominal compensation per employee in the euro area since 1999 needs to be seen in conjunction with the very low wage growth recorded in Germany. Excluding Germany from the euro-area aggregate would yield an average growth rate of 3\% over the period 1999-2006 (Graph 3). 


\section{Graph 3}

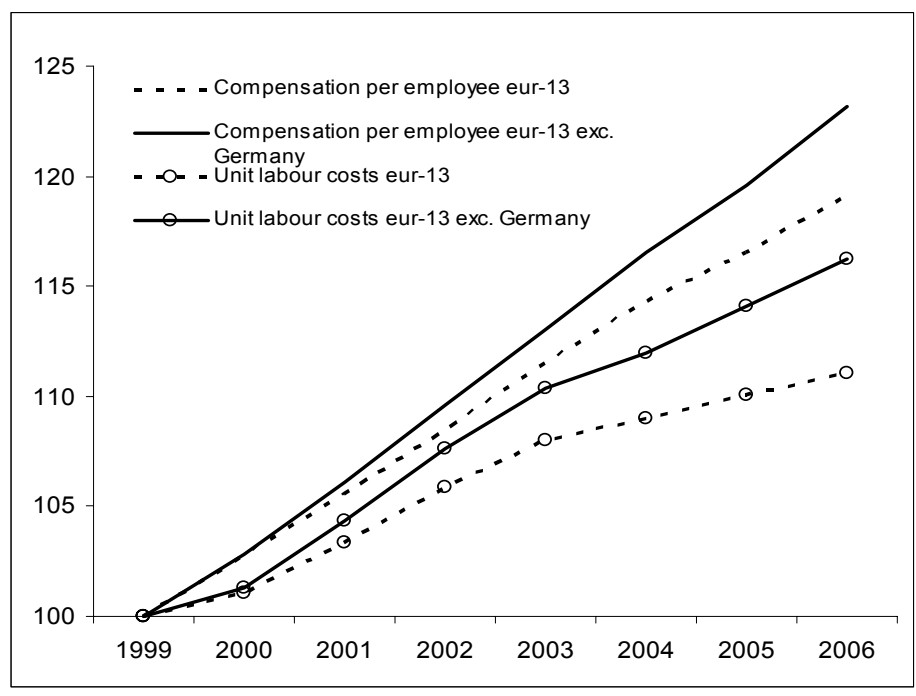

Source: Ameco

Cross-country differences in wage and labour cost developments need not be a particular cause for concern, but may simply reflect the efficient working of market forces and warranted intraarea adjustment between countries. First, when countries start from different wage cost and price levels, convergence towards a common wage cost and price level necessarily entails a deviation in wage cost inflation rates. When the long-run relative wage cost and price level across countries is a function of relative incomes faster growing country may have temporarily higher inflation in the transition to a new long-run real exchange rate equilibrium. Secondly, dispersion in ULC growth rates across euro area countries may simply reflect the market response to divergent cyclical positions. Countries with depressed cyclical conditions relative to those of their main trading partners should experience less inflationary pressures, eventually leading to a downward adjustment in their prices relative to those of their main partners in the area. In a frictionless economy, flexible aggregate wages obviate the need for output to respond temporary demand shocks. In contrast, aggregate wage rigidity increases short-term output fluctuations around the potential output growth path.

Changes in relative wages and prices of different sectors are also needed to absorb sectoral shocks. For example, in response to a demand shift toward non-tradable goods in a specific country, the competitive position of its traded sector should deteriorate in order to reallocate resources away from this sector. Changes in wages and prices of the tradable relative to the nontradable sector may contribute to the achievement of a new equilibrium ${ }^{2}$ in the market of nontraded goods (Aizenman and Frenkel, 1986) and, through the economy's budget constraint, reduce trade imbalances (Dornbusch, 1974). In this case, the adjustment to shocks works mainly through changes in relative prices, with net exports and the supply of non-traded goods acting as factors contributing to the adjustment of divergences in GDP growth. Nevertheless, the long-term steady state of the economy will also depend on the trend in net foreign assets. Clearly, any sustained divergence in wage cost inflation systematically eroding countries' relative competitive position should be a reason of serious concern. Moreover, localized transitory shocks resulting in real effective exchange rate appreciation could engender a boom-bust cycle, if there are

2 Changes in the nominal exchange rate cannot yield the new equilibrium because changing relative prices and relative wages involves two targets, which cannot be addressed with only one instrument. A combination of exchange rate and fiscal policies can contribute to achieving a new equilibrium but only temporarily without a change in the long-term structure of relative wages. 
persistence mechanisms at work that lead to overshooting in wage and price dynamics, and ultimately increase the unemployment sacrifice ratio - i.e. the increase in unemployment needed to trigger a change in competitiveness (Blanchard, 2006). Moreover, nominal wage rigidities create further persistence of the shocks, in addition to the persistence accounted for by the exogenous shocks themselves, and generate price and inflation dispersion (Altissimo et al., 2004). Differences across countries in wage stickiness are a source of heterogeneous adjustment to both common and country-specific supply shocks, which affects output and inflation locally and union-wide. ${ }^{3}$ Hence, an increase in all countries of real and nominal wage flexibility reduces the sensitivity of the euro-area output to common and country-specific shocks. Also, different responses of sectoral wages to real shocks are required when shocks are sector specific or workers are heterogeneous (Aizenman and Frenkel, 1986).

Over the cycle, one would expect a positive relationship between price and wage adjustments and deviations of output from trend. As suggested by Graph 4, the response of relative unit labour costs to cyclical conditions before and after 1999 differs across countries. Countries such as Ireland, France and Spain, with comparatively positive output gaps during the euro-area years, experienced an increase in their relative wages. In Spain, productivity growth continued along the unfavourable trend established during the pre-1999 period. In contrast, in France and, especially, in Ireland, a comparatively higher growth of productivity contributed to the containment of costs pressures. On the other hand, countries with relatively lower cyclical pressures, such as Italy, the Netherlands and Portugal, were not able to contain their costs pressures. Within this group, Italy witnessed comparatively unfavourable productivity growth, while the Netherlands and Portugal experienced excessive wage growth, which had already taken place in Portugal in the pre-1999 years. Despite the relatively weak cyclical conditions of Greece, its relative unit labour costs grew as much as in Spain, mainly because of comparatively strong wage pressures. Finally, the competitiveness gains of Germany were driven by a significant downward adjustment in relative wages, gradually correcting the overshooting of the unification, while those of Austria were determined by a positive differential in productivity growth.

Compared to the pre-1999 period, during the early years of monetary union there was a change in the contribution of relative wages and productivity to the dynamics of unit labour costs. Before the creation of the euro area, wage developments were the main source of the deterioration in cost competitiveness in Greece, Portugal, Spain and Italy. In addition, with Portugal as the only exception, the unfavourable productivity developments of these countries contributed to a worsening of their competitive position. Among those countries that gained in cost competitiveness in the pre-1999 years, Ireland and Finland benefited from a favourable differential in productivity growth, while wage disinflation prevailed in Germany and, to a lesser extent, in France.

Since the launch of the euro in 1999, Germany has experienced significant competitiveness gains that appear to be largely driven by wage growth, which continued to be relatively more restrained than in the other euro-area countries, especially in the more recent years. Indeed, between 2003 and 2005 , Germany scored about $6 \%$ of the $10 \%$ gains in cost competitiveness observed in the post-1998 years. In countries where costs competitiveness worsened in the years before 1999,

\footnotetext{
In an inter-temporal general equilibrium model of currency union, Andersen (2004) shows that shocks are transmitted via the current account, through changes in the terms of trade, and propagated differently across heterogeneous national labour markets. In response to common and country-specific shocks, more real and nominal wage flexibility make EU-wide aggregate output less sensitive to shocks. Also greater real and nominal wage flexibility leads to less variability of output, especially in the case of real wage flexibility when the initial flexibility is low. In the case of common shocks, more domestic and nominal wage flexibility has ambiguous effects because it increases the volatility of the terms of trade. Finally, in the case of country specific shock, more real flexibility in the domestic and foreign countries contributes to less domestic output variability. Greater nominal wage flexibility in the domestic country reduces output variability, while more nominal rigidity in the foreign country reduces output variability when the initial degree of rigidity is low. In contrast, it increases domestic output variability when the degree of rigidity is high.
} 
unit labour costs kept rising more than in the remaining euro-area countries. Within this group, the unfavourable productivity growth differential explains the deterioration of the competitiveness position of Italy and, to a lesser extent, of Spain. In contrast, the favourable developments of productivity in Greece were not sufficient to keep relative unit labour costs in check.

Overall, the observed patterns of relative labour cost developments across euro area countries suggest overall that intra-area adjustment mechanisms are at work in the euro area, although slow and often costly in terms of output and employment. The evidence from some of the smaller countries participating in EMU such as Portugal also indicates that wage growth out of line with productivity may not be quickly self-correcting. Rather, the ensuing loss of competitiveness may build up over quite some time before the inevitable, yet then even more painful, adjustment processes will kick in. 


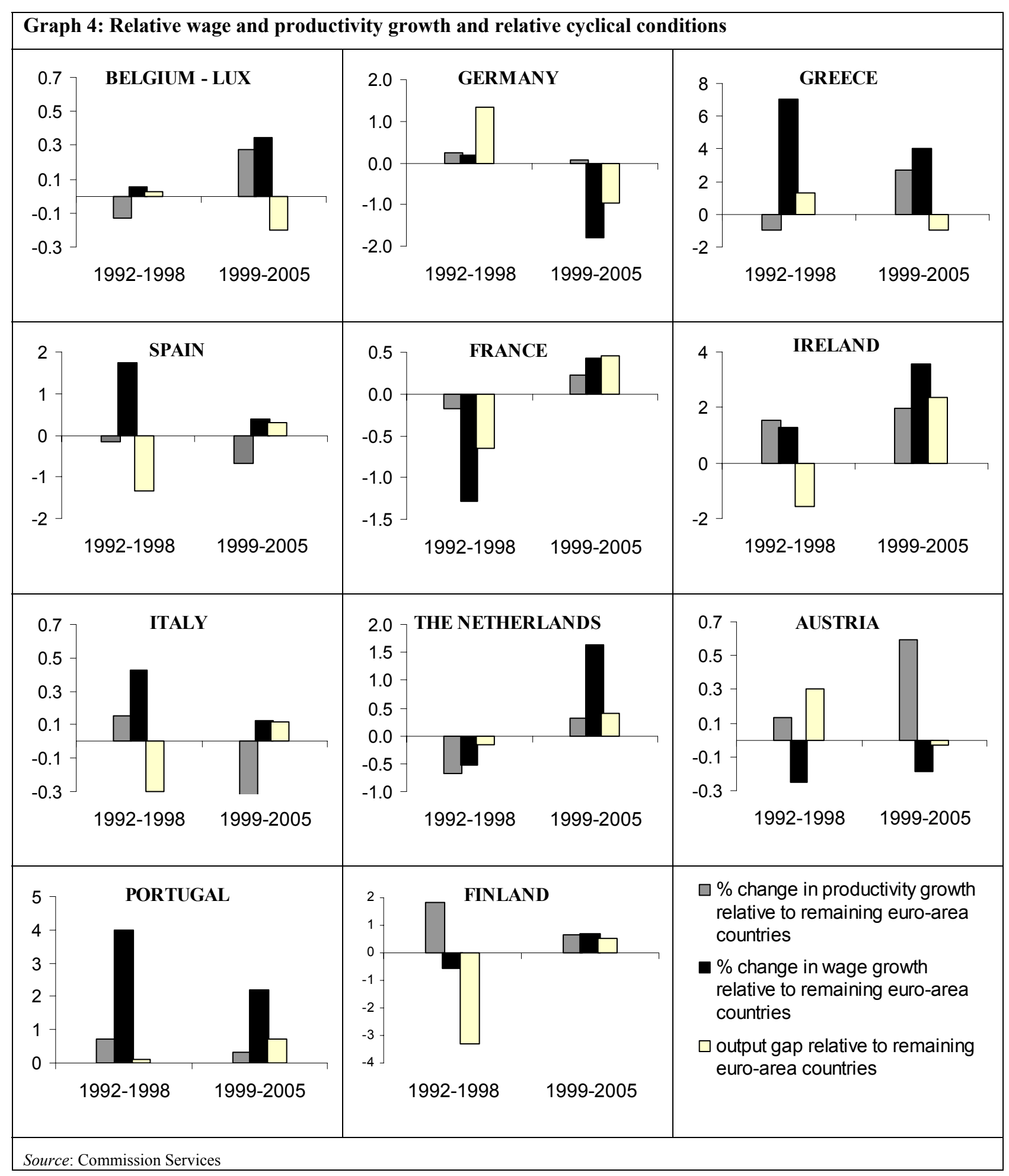




\section{Phillips curve estimates}

In order to evaluate the degree of nominal and wage rigidity, this section presents econometric estimates of Phillips-curve-type wage equations. The standard Phillips curve suggests a relationship between the change of wage inflation and the unemployment gap, with the relationship affected by various shocks, for example to labour productivity or the terms of trade. The rigidity of real wages and their response to productivity affects the response of the NAIRU to mark-up shocks.

\subsection{The model}

The model is based on the theoretical motivation of a wage Phillips curve presented in Blanchard and Katz (1999). The basic idea, consistent with the standard models of wage setting (e.g. Booth, 1995; Pissarides, 1998) is that the real wages expected by workers, $\omega^{\mathrm{e}}$, are determined as a weighted average of the reservation wage, $b_{t}^{e}$, and the current productivity level, $\mathrm{y}_{\mathrm{t}}-1_{\mathrm{t}}$. Transitory deviations of expected real wages from this wage norm depend on the state of the labour market, captured by the unemployment rate, $\mathrm{u}_{\mathrm{t}}$ :

$$
\omega_{t}^{e}=\mu b_{t}^{e}+(1-\mu)\left(y_{t}-l_{t}\right)-\beta u_{t}+\varepsilon_{t}^{\omega}
$$

The term $\varepsilon_{t}^{w}$ is a shock to the wage-setting rule that can be autocorrelated. The reservation wage in turn is determined as a weighted average of the lagged real wages and productivity:

$$
b_{t}=a+\lambda \omega_{t-1}+(1-\lambda)\left(y_{t}-l_{t}\right)
$$

Substituting the expression for the reservation wage into the wage equation (1) gives the following expression

$$
\omega_{t}^{e}=\mu a+\mu \lambda \omega_{t-1}+(1-\mu \lambda)\left(y_{t}-l_{t}\right)-\beta u_{t}+\varepsilon_{t}^{\omega}
$$

which can be written as an equilibrium error correction mechanism (EqCM)

$$
\begin{aligned}
& \Delta w_{t}=\mu a+\Delta p_{t-1}^{e}-(1-\mu \lambda)\left[\omega_{t-1}-\left(y_{t-1}-l_{t-1}\right)\right]+(1-\mu \lambda) \Delta\left(y_{t}-l_{t}\right)-\beta u_{t}+\varepsilon_{t}^{\omega} \\
& \Delta w_{t}=\mu a+\Delta p_{t-1}^{e}-(1-\mu \lambda) \omega s_{t-1}+(1-\mu \lambda) \Delta\left(y_{t-1}-l_{t-1}\right)-\beta u_{t}+\varepsilon_{t}^{\omega}
\end{aligned}
$$

The derived Phillips curve is an hybrid cross-over type (i.e. with price inflation in the wage Phillips curve) composed by three elements in addition to traditional unemployment rate capturing demand pressures in the labour market. A first term is the wage share which behaves as an error correction mechanism, implying that real wages adjust to trend labour productivity. An increase in the wage share is equivalent to a temporary labour demand shock implying that any increase in the wage share in one year triggers an adjustment dynamics that bring the level of real wages to be in line with productivity. The second term is the labour productivity growth. To keep the wage share far from growing or declining without limit, changes in productivity have a proportional impact on the wage inflation. The impact is full only when the real wages expected by workers do not depends on the reservation wage (i.e. $\mu=0$ ) or when they are not set as a function of previous earnings. The third additional term is the expected price inflation. Temporary changes in the corrected anticipated price inflation are transferred one to one on temporary wage inflation. In practice, adjustment in nominal wages can take time because of institutional rigidities (e.g. staggered contracts of fixed length) or incomplete and imperfect information on the inflationary climate. The error correction appears in the Phillips curve if the reservation wage depends on productivity and little on little on past real wages. Hence, $\mu \lambda$ 
measures the joint effect on the real wages of productivity and the persistence in real wages. When different from zero According to Blanchard and Katz the difference between the US and Europe lies on the absence of the wage level in the US wage equation (i.e. there is no EqCM in the US Phillips curve).

In this paper we make operational the theoretical wage-Phillips curve, modelling inflation expectations as an adaptive adjustment mechanism, which introduces some inertia in the adjustment of wages to inflation:

$$
\pi_{t}^{e}=\gamma \pi_{t-1}+(1-\gamma) \pi_{t-1}^{e}
$$

where $\gamma$ measures the degree to which nominal wages are responsive to lagged inflation (nominal wage rigidity). With this assumption we depart from New Keynesian Phillips curve approach built on either the staggered contracts Calvo model by Gali et al (1999) or on the dynamic model of pricing behaviour with adjustment costs of Batini et al (2005). The use adaptive expectations may be appropriate to capture the relevance of the inflationary climate where the economy is embedded. In Gali et al (2001), backward looking firms set the current price seeing how firms set the price in the previous period making a correction for inflation using lagged inflation as predictor. Here we assume that as in Chen et al. (2005) that agents do not forget the sequence of past inflation rates. Moreover, adaptive expectations should be more appropriate than inflation lagged by one year only to capture the optimal indexation rule when wages contracts are renegotiated every two or three years.

Inserting (5) in (4) allows to obtain the lagged uncorrected expectations, $(1-a) \pi_{t-1}^{e}$, from the model. We assume that when forming the expectations about current inflation, agents take into account the error done in period t-1. Using this model based expectation in (4) yields the following wage-Phillips curve.

$\Delta^{2} w_{t}=\mu \gamma a-\gamma \Delta \omega_{t-1}+\rho\left(\Delta^{2} z_{t}-\Delta \omega s_{t-1}\right)+\gamma \rho\left(\Delta z_{t-1}-\omega s_{t-2}\right)-\beta \Delta u_{t}-\gamma \beta u_{t-1}+\varepsilon_{t}^{\omega}-(1-\gamma) \varepsilon_{t-1}^{\omega}$

where

$\rho=(1-\mu \lambda)$ and $z=y-l$

If $0<\gamma<1$, the equation above can be rewritten as an ARDL:

$\Delta^{2} w_{t}=\mu \gamma a-\gamma \Delta \omega_{t-1}+\rho\left(\Delta^{2} z_{t}-\Delta \omega s_{t-1}\right)+\gamma \rho\left(\Delta z_{t-1}-\omega s_{t-2}\right)-\beta \Delta u_{t}-\gamma \beta u_{t-1}+\varepsilon_{t}^{\omega}(1-(1-\gamma) L)$

where $\mathrm{L}$ is the lagged operator $L \varepsilon_{t}=\varepsilon_{t-1}$

$\Delta^{2} w_{t}=\mu a-\sum_{j=1}^{\infty} \rho^{j} \Delta^{2} w_{t-j}+\sum_{j=0}^{\infty} \rho^{j}\left[-\gamma \Delta \omega_{t-1-j}+\rho\left(\Delta^{2} z_{t-j}-\Delta \omega s_{t-1-j}\right)+\gamma \rho\left(\Delta z_{t-1-j}-\omega s_{t-2-j}\right)-\beta \Delta u_{t-j}-\gamma \beta u_{t-1-j}\right]+\varepsilon_{t}$

(8)

where $\varepsilon_{t}$ is a white noise disturbance. Depending on how wages adjust to expected inflation affects the dynamic response of wages to the unemployment gap as given by different distributed lag schemes of the unemployment gap in the Phillips curve.

Labour demand is formulated in terms of a first order condition for an optimising firm, which equates the real wage to the marginal revenue product of labour. The MRPL can be decomposed into average labour productivity and a residual term (ws) which can contain other factors such as a mark-up or efficiency shocks. In symbols,

$$
w_{t}-p_{t}=\left(y_{t}-l_{t}\right)+w s_{t}
$$


In the case of firms producing differentiated goods and engaging in price competition equation 9 can be seen as a price setting formula. The price set by each firm is a mark-up over marginal cost deflated by a productivity term. Hence, the equilibrium condition for the firm gives a level of wages consistent with the price of the final products and the level of productivity. ${ }^{4}$

The theoretical model outlined above suggests that shocks to labour demand or to the (log) markup captured by the inverse of the wage share ws and represented by the wage share could play a crucial role for wages. A positive mark-up shock reduces real wage relative to productivity. The effect of changes in the mark-up depends on the values of $\rho$. If $\rho=0$ workers will take into account this shock in the future wage bargaining and the effect on wage inflation will be temporary. If $\rho>0$, the effect of shocks to the mark-up will influence wage inflation in subsequent years.

\subsection{Empirical results}

Equation 8 is estimated first without any lag structure and then adding further lags of the variables as required to get white noise disturbances. The sample consists of annual observations for 12 euro-area countries over the period 1980-2005. Variables are taken from DG ECFIN's AMECO database. With the exception of the unemployment rate, all variables are in logs. The first column reports the estimates of the fixed effect estimator. All coefficients turned out to be statistically significant with the expected signs. It may be realistic to have different error variances for the different cross-sections. A formal test of heteroskedasticity confirms this expectation. The group-wise LR test, distributed as a chi-squared with G-1 degrees of freedom where $\mathrm{G}$ is the number of groups in the sample (i.e. the 12 euro-area countries), is equal to 86.45 . With a $5 \%$ critical value of 19.68 , the hypothesis of homoscedasticity is rejected. With crosssection heteroskedasticity the OLS standard errors will be inconsistent (Greene pp 219). Columns 2 and 3 display the estimates of the equation 7, using the White and the Beck and Katz (1995) correction with heteroskedastic-consistent covariance matrix for pooled regressions. Columns (4) and (5) report the fixed effects FGLS estimator corrected respectively for heteroskedasticity and for heteroskedasticity and contemporaneously correlated disturbances.

The Baltagi and Li (1995) autocorrelation test is not conclusive, as the chi-squared version of the test rejects the hypothesis of no autocorrelation while the $\mathrm{N}(0,1)$ version leads to accept the hypothesis of no autocorrelation at $5 \%$ level of confidence 5 . The possible autocorrelation invite to model the dynamics as predicted by a model with persistent inflation. To account for the serial correlation, lags are included to the benchmark equation (table 2). It turns out that a lagged dependent variable is not sufficient to have white noise disturbances while adding further lags of the explanatory variables is sufficient to have well behaved errors (Column 6 our preferred specification).

We are interested in the estimates of three parameters $(\beta, \gamma$, and $\rho)$. The point estimate of the semi-elasticity of the real wage to unemployment rate $(\beta)$ is between 0.2 and 0.4 . In the case of our preferred specification, an increase in unemployment by 1 percentage point leads to a downward wage adjustment of about $0.3 \%$. The econometric Phillips curve estimates suggest the existence of a significant degree of nominal wage rigidity in the euro area economy. The coefficient that captures the inflation persistence $(\gamma)$ between 0.4 and 0.5 implies that about $50 \%$ of the inflation of the previous year is passed on into current wage growth. This value suggests a

\footnotetext{
${ }^{4}$ The variable $\mu$ can itself be a function of various factors, such as the market power of firms and the user cost of capital.

${ }^{5}$ Autocorrelation is tested with the LM test for serial correlation and individual effects (Baltagi and Li, 1995) distributed as a chi-squared with 1 degree of freedom and asymptotically as a $\mathrm{N}(0,1)$.
} 
considerable effect of the inflationary climate on current developments of wage inflation. The coefficient of the (log-) wage share is consistent with a Blanchard-Katz error correction term. If real wages are higher than productivity, or similarly if the mark up falls, there is a correction in the following year in the growth rate of nominal wages that keeps real wages tied with productivity. According to our estimate only $40 \%$ of the deviation is closed in one year, which also implies that through the error correction mechanism further persistence is added to the wage growth.

The empirical specification should be interpreted with caution as it covers different countries and periods with different monetary regimes. Consequently, the stability of our results is checked both across time and countries. The stability over time is established through recursive estimation of the empirical model, including at each estimation stage one year more up to recovering the entire sample. The findings of this exercise are reproduced in graphs 5a-c where the point estimates of the parameters appear with the two standard error regions defining the 5\% significance range. The estimated elasticity of the coefficient capturing the extent of nominal wage rigidity, $\gamma$, is stable and significant over sub-samples and not just over the whole period, as it would be if significance reflected only chance. The response of wages to unemployment becomes stronger at the end of the 1990s, when the monetary union was approaching, declines gradually during the first three years of 2000s and picks up slightly in 2004 and 2005. However, time stability of $\beta$ cannot be excluded. The real rigidity determined in the Blanchard and Katz model by the wage bargaining rule and captured in the empirical specification by the coefficient of the error correction mechanism declines gradually over time. The value of $\rho$ declines sharply when 2001 is added to the equation, possibly due to the enhanced credibility of the antiinflationary monetary policy in the early years of EMU. The downward trend in the recursive estimate of $\rho$ implies that any deviation of real wages from productivity leads to an adjustment in wages which falls over time. This finding is consistent with the moderate wage pressures of the late 1990s early 2000s. However, the point estimates fall approximately in the same two standard errors region, implying again stability over time.

Our findings might be affected by the relative small number of countries in the sample. As robustness check we have re-estimated the model excluding from the sample one country at a time. Graphs 6a-c report the values of $\rho, \gamma$, and $\beta$ together with the two standard errors region which defines the 5\% significance range. Each point gives the point estimate when the country indicated on the horizontal axis is excluded from the sample. In this case we are able to identify whether the estimates for the whole period are driven by a specific outlier country. While the estimate of wage inflation persistence is stable across countries, the estimated values of $\rho$ and $\beta$ are influenced by respectively, Ireland and Finland being in the sample. The point estimates of $\rho$ slightly rises from 0.36 to 0.43 when Ireland is excluded from the sample. Similarly, when Finland is excluded from the sample the semi-elasticity of real wages to unemployment falls from 0.3 to 0.12 . However, since the $5 \%$ significance range includes 0 it cannot be excluded that the real wages are rigid with respect to changes in the unemployment rate. 


\begin{tabular}{|c|c|c|c|c|c|}
\hline \multicolumn{6}{|l|}{ Table 1} \\
\hline Variable & LSDV & White & PCSE & FGLS (1) & FGLS (2) \\
\hline $\mathrm{D} \omega(-1)$ & $\begin{array}{l}-0.37 \\
(-6.5)\end{array}$ & $\begin{array}{c}-0.37 \\
(-4.5)\end{array}$ & $\begin{array}{l}-0.37 \\
(-4.9)\end{array}$ & $\begin{array}{c}-0.39 \\
(-6.85)\end{array}$ & $\begin{array}{c}-0.46 \\
(-10.4)\end{array}$ \\
\hline $\mathrm{D} 2 \mathrm{z}-\omega \mathrm{s}(-1)$ & $\begin{array}{l}0.35 \\
(6.0)\end{array}$ & $\begin{array}{l}0.36 \\
(4.7)\end{array}$ & $\begin{array}{c}0.36 \\
(5.02)\end{array}$ & $\begin{array}{c}0.33 \\
(5.81)\end{array}$ & $\begin{array}{l}0.35 \\
(9.8)\end{array}$ \\
\hline $\mathrm{Dz}(-1)-\omega \mathrm{s}(-2)$ & $\begin{array}{l}0.15 \\
(5.3)\end{array}$ & $\begin{array}{l}0.15 \\
(4.3)\end{array}$ & $\begin{array}{l}0.15 \\
(4.2)\end{array}$ & $\begin{array}{c}0.16 \\
(5.97)\end{array}$ & $\begin{array}{l}0.18 \\
(8.3)\end{array}$ \\
\hline $\mathrm{Du}$ & $\begin{array}{l}-0.35 \\
(-3.2)\end{array}$ & $\begin{array}{l}-0.35 \\
(-3.1)\end{array}$ & $\begin{array}{l}-0.35 \\
(-3.3)\end{array}$ & $\begin{array}{l}-0.35 \\
(-3.8)\end{array}$ & $\begin{array}{l}-0.22 \\
(-3.8)\end{array}$ \\
\hline $\mathrm{u}(-1)$ & $\begin{array}{c}-0.07 \\
(-1.75) \\
\end{array}$ & $\begin{array}{l}-0.07 \\
(-1.5) \\
\end{array}$ & $\begin{array}{l}-0.07 \\
(-1.6) \\
\end{array}$ & $\begin{array}{l}-0.097 \\
(-2.5) \\
\end{array}$ & $\begin{array}{l}-0.06 \\
(-2.6) \\
\end{array}$ \\
\hline $\mathrm{R}^{2}$ & 0.37 & 0.37 & 0.37 & 0.38 & 0.37 \\
\hline S.E. of regression & 1.63 & 1.63 & 1.63 & 1.63 & 1.63 \\
\hline Fixed effects & Yes & Yes & Yes & Yes & Yes \\
\hline $\begin{array}{l}\text { BL LM test for } \\
\text { autocorrelation }\end{array}$ & $\begin{array}{c}1.42 \\
\chi^{2}(1)=0.23 \\
\mathrm{~N}(0,1)=0.077\end{array}$ & $\begin{aligned} 1.45 \\
\chi^{2}(1)=0.23 \\
\mathrm{~N}(0,1)=0.073\end{aligned}$ & $\begin{aligned} 1.45 \\
\chi^{2}(1)=0.23 \\
\mathrm{~N}(0,1)=0.073\end{aligned}$ & $\begin{array}{c}1.64 \\
\chi^{2}(1)=0.20 \\
\mathrm{~N}(0,1)=0.05\end{array}$ & $\begin{array}{c}2.69 \\
\chi^{2}(1)=0.10 \\
\mathrm{~N}(0,1)=0.036^{* *}\end{array}$ \\
\hline $\begin{array}{l}\text { Groupwise } \\
\text { Heteroskedasticity }\end{array}$ & $\begin{array}{c}86 \\
\chi^{2}(11)=0.23\end{array}$ & & & & \\
\hline $\begin{array}{l}\text { PCSE is the Beck } \\
\text { heteroskedasticity } \\
\text { heteroskedasticity } \\
\text { values for the chi-s } \\
\text { test and the critical }\end{array}$ & $\begin{array}{l}\text { tz (1995) robu } \\
\text { nits is used. F } \\
\text { temporaneously } \\
\text { nd one-sided N } \\
\text { the chi-squared }\end{array}$ & $\begin{array}{l}t \text { correction fo } \\
\text { SLS (1): FGL } \\
\text { correlated resi } \\
0,1) \text { are report } \\
\text { distribution at }\end{array}$ & $\begin{array}{l}\text { the standard e } \\
\text { for heterosked } \\
\text { luals. For BL L } \\
\text { d. For the Group } \\
\% \text { significance }\end{array}$ & $\begin{array}{l}\text { or. A Covariar } \\
\text { ticity residual } \\
\text { I test, the valu } \\
\text { ise Heterosced } \\
\text { yel are reportec }\end{array}$ & $\begin{array}{l}\text { estimator robust to } \\
\text { GLS(2): FGLS for } \\
\text { the test and its p- } \\
\text { city the value of the }\end{array}$ \\
\hline
\end{tabular}

\begin{tabular}{|c|c|c|c|c|c|c|}
\hline Table 2 & & & & & & \\
\hline Variable & LSDV & White & PCSE & FGLS (1) & FGLS (2) & FGLS (2) \\
\hline $\mathrm{D} 2 \mathrm{w}(-1)$ & $\begin{array}{l}0.09 \\
(1.6)\end{array}$ & $\begin{array}{l}0.09 \\
(1.3) \\
\end{array}$ & $\begin{array}{l}0.09 \\
(1.3) \\
\end{array}$ & $\begin{array}{l}0.09 \\
(1.7) \\
\end{array}$ & $\begin{array}{l}0.08 \\
(1.6) \\
\end{array}$ & $\begin{array}{c}0.11 \\
(2.28) \\
\end{array}$ \\
\hline $\mathrm{D} \omega(-1)$ & $\begin{array}{l}-0.38 \\
(-6.3) \\
\end{array}$ & $\begin{array}{l}-0.38 \\
(-4.6) \\
\end{array}$ & $\begin{array}{l}-0.38 \\
(-5.0) \\
\end{array}$ & $\begin{array}{l}-0.41 \\
(-6.7) \\
\end{array}$ & $\begin{array}{l}-0.50 \\
(-9.9) \\
\end{array}$ & $\begin{array}{c}-0.47 \\
(-10.8)\end{array}$ \\
\hline $\mathrm{D} 2 \mathrm{z}-\omega \mathrm{s}(-1)$ & $\begin{array}{l}0.37 \\
(6.2)\end{array}$ & $\begin{array}{l}0.37 \\
(4.8)\end{array}$ & $\begin{array}{l}0.37 \\
(5.1)\end{array}$ & $\begin{array}{l}0.35 \\
(6.1)\end{array}$ & $\begin{array}{l}0.36 \\
(9.6)\end{array}$ & $\begin{array}{c}0.36 \\
(10.1)\end{array}$ \\
\hline $\mathrm{Dz}(-1)-\omega \mathrm{s}(-2)$ & $\begin{array}{l}0.15 \\
(4.8) \\
\end{array}$ & $\begin{array}{l}0.15 \\
(3.7) \\
\end{array}$ & $\begin{array}{l}0.15 \\
(3.8) \\
\end{array}$ & $\begin{array}{l}0.15 \\
(5.3) \\
\end{array}$ & $\begin{array}{l}0.17 \\
(6.9) \\
\end{array}$ & $\begin{array}{c}0.11 \\
(5.08) \\
\end{array}$ \\
\hline$\overline{\mathrm{Du}}$ & $\begin{array}{l}-0.38 \\
(-3.2)\end{array}$ & $\begin{array}{l}-0.38 \\
(-3.5) \\
\end{array}$ & $\begin{array}{l}-0.38 \\
(-3.5) \\
\end{array}$ & $\begin{array}{l}-0.39 \\
(-4.2) \\
\end{array}$ & $\begin{array}{c}-0.25 \\
(-3.96) \\
\end{array}$ & $\begin{array}{c}-0.27 \\
(-4.88) \\
\end{array}$ \\
\hline $\mathrm{u}(-1)$ & $\begin{array}{c}-0.07 \\
(-1.69)\end{array}$ & $\begin{array}{l}-0.07 \\
(-1.5)\end{array}$ & $\begin{array}{l}-0.07 \\
(-1.6)\end{array}$ & $\begin{array}{c}-0.11 \\
(-2.85)\end{array}$ & $\begin{array}{c}-0.08 \\
(-3.10)\end{array}$ & $\begin{array}{l}-0.06 \\
(-2.70)\end{array}$ \\
\hline $\mathrm{D} \omega(-3)$ & & & & & & $\begin{array}{c}0.09 \\
(2.54)\end{array}$ \\
\hline $\mathrm{D} 2 \mathrm{z}(-1)-\cos (-2)$ & & & & & & $\begin{array}{c}0.08 \\
(2.49)\end{array}$ \\
\hline $\mathrm{D} 2 \mathrm{z}(-3)-\omega \mathrm{s}(-4)$ & & & & & & $\begin{array}{c}0.05 \\
(1.94)\end{array}$ \\
\hline $\mathrm{R}^{2}$ & 0.38 & 0.38 & 0.37 & 0.38 & 0.54 & 0.69 \\
\hline S.E. of regression & 1.56 & 1.59 & 1.59 & 1.56 & 1.01 & 1.03 \\
\hline Fixed effects & Yes & Yes & Yes & Yes & Yes & Yes \\
\hline Dummy reunif. & & & & & & Yes \\
\hline $\begin{array}{l}\text { BL LM test for } \\
\text { autocorrelation }\end{array}$ & $\begin{aligned} & 0.62 \\
& \chi^{2}(1)=0.43 \\
& \mathrm{~N}(0,1)=0.30 \\
&\end{aligned}$ & $\begin{aligned} 0.62 & \\
\chi^{2}(1) & =0.43 \\
\mathrm{~N}(0,1) & =0.30\end{aligned}$ & $\begin{aligned} 0.62 & \\
\chi^{2}(1) & =0.43 \\
\mathrm{~N}(0,1) & =0.30\end{aligned}$ & $\begin{array}{c}0.93 \\
\chi^{2}(1)=0.33 \\
\mathrm{~N}(0,1)=0.18\end{array}$ & $\begin{array}{c}0.93 \\
\chi^{2}(1)=0.16 \\
\mathrm{~N}(0,1)=0.025^{*}\end{array}$ & $\begin{array}{l}\chi^{2}(1)=1.6(0.20) \\
\mathrm{N}(0,1)=1.3(0.10)\end{array}$ \\
\hline $\begin{array}{l}\text { Groupwise } \\
\text { Heteroscedasticity }\end{array}$ & $\begin{array}{c}86.45 \\
\chi^{2}(11)=0.23\end{array}$ & & & & & \\
\hline \multicolumn{7}{|c|}{$\begin{array}{l}\text { PCSE is the Beck and Katz (1995) robust correction for the standard error. A Covariance estimator robust to } \\
\text { heteroscedasticity across-units is used. FGLS (1): FGLS for heteroscedastic residuals; FGLS(2): FGLS for } \\
\text { heteroscedastic and contemporaneously correlated residuals. For the LM test value of the test and p-values (in } \\
\text { parentheses) for the chi-squared and one-sided N(0,1) are reported. For the Groupwise Heteroscedasticity value of the } \\
\text { test and the critical level of the chi-squared distribution at } 5 \% \text { significance level are reported. }\end{array}$} \\
\hline
\end{tabular}



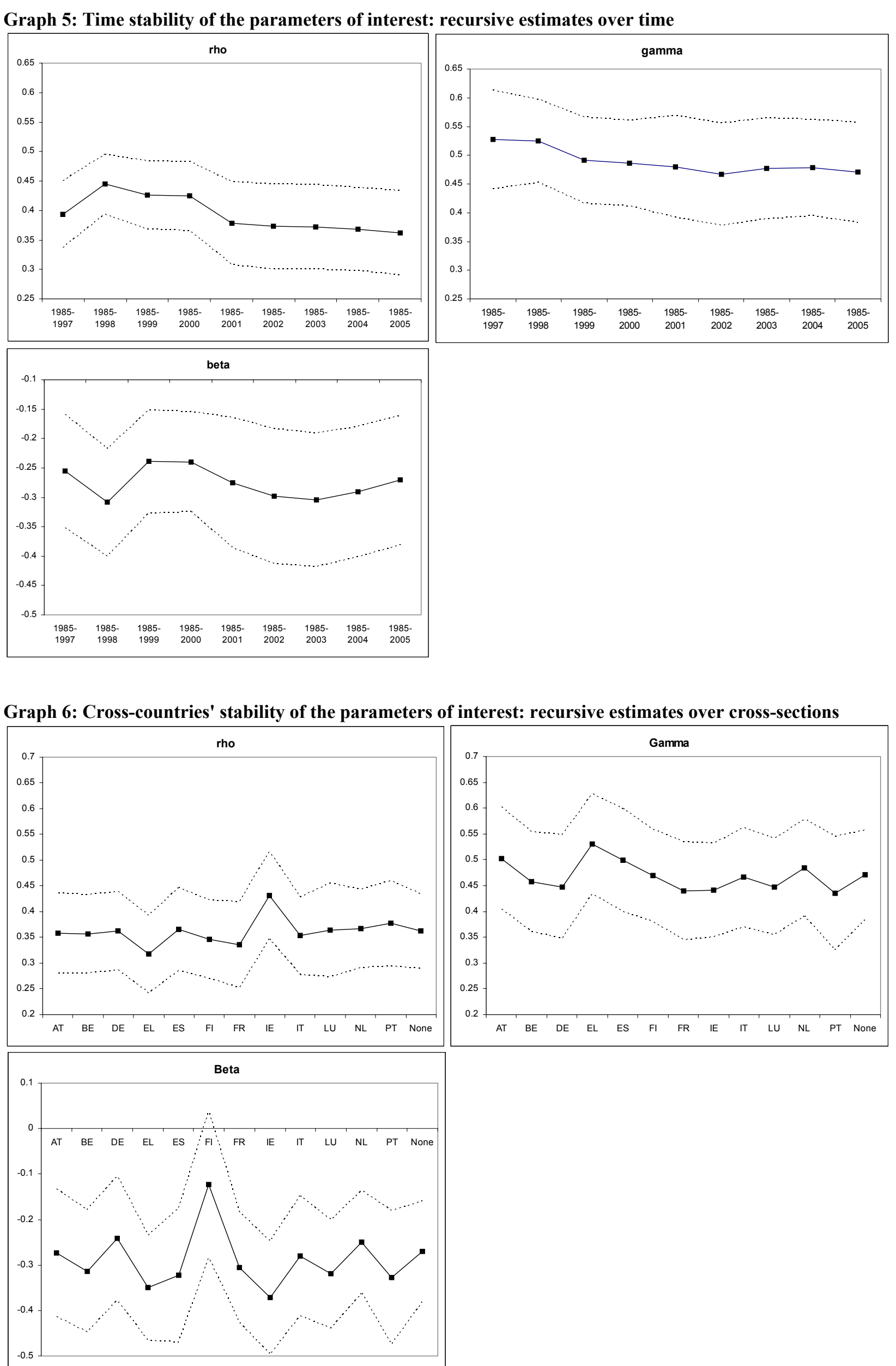

17 


\subsection{Do euro-area countries have the same degree of real and nominal wage rigidity?}

The fixed effect GLS estimator control for time invariant country specific characteristics but does not admit slope to differ across countries. Pesaran and Smith (1995) showed that the real problem with dynamic panels stems from the possible heterogeneity in the model parameters. Traditional panel data techniques can produce inconsistent and potentially misleading estimates of the average values of the parameters, unless the slope coefficients are identical. The inconsistency does not disappear even when the size of the cross-section and of the time periods is large. To analyse the conformity of euro-area countries we use the Chow test of poolability for panel data modified by Roy, Zellner, Baltagi (RZB) for non-spherical disturbances and the Wald test (Table 1). Poolability is tested for all coefficients, for all slopes allowing for fixed effects and for each parameter at a time forcing the others to be the same across countries. The RZB test leads to reject the poolability of all coefficients (both slopes and fixed effects). However, allowing for varying intercepts (i.e. estimating the restricted model with the Within estimator), the value of test come close to the $10 \%$ significance threshold. When we test poolability of each slope, the value of the test is on the borderline between the acceptance and rejection regions of poolability at 5\% significance level. On basis of the Wald, test poolability is rejected in all cases at standard significance level. However, the hypothesis that the semi-elasticity of real wages to unemployment is the same across countries is accepted at $1 \%$ significance level.

Table 3

\begin{tabular}{|l|c|c|c|c|c|}
\hline \multicolumn{7}{|c|}{ Poolability tests: $R$ RB test } \\
\hline & $\begin{array}{c}H_{0}: \text { all coefficients } \\
\text { are poolable }\end{array}$ & $\begin{array}{c}H_{0}: \text { all slopes are } \\
\text { poolable }\end{array}$ & $H_{0}: \rho_{i}=\rho$ & $H_{0}: \gamma_{i}=\gamma$ & $H_{0}: \beta_{i}=\beta$ \\
\hline Statistic & $\mathrm{F}(110,132)=1.18$ & $\mathrm{~F}(99,132)=1.24$ & $\mathrm{~F}(88,132)=1.29$ & $\mathrm{~F}(88,132)=1.28$ & $\mathrm{~F}(88,132)=1.33$ \\
\hline p-value & 0.18 & 0.12 & 0.09 & 0.096 & 0.07 \\
\hline
\end{tabular}

\begin{tabular}{|l|c|c|c|c|}
\hline \multicolumn{5}{|c|}{ Poolability tests: Wald test } \\
\hline & $\begin{array}{c}H_{0}: \text { all slopes are } \\
\text { poolable }\end{array}$ & $H_{0}: \rho_{i}=\rho$ & $H_{0}: \gamma_{i}=\gamma$ & $H_{0}: \beta_{i}=\beta$ \\
\hline Statistic & $\begin{array}{c}\chi(35)^{2}=481.7(0.0) \\
\mathrm{F}(35,197)=13.8(0.0)\end{array}$ & $\begin{array}{c}\chi(11)^{2}=33.3(0.0) \\
\mathrm{F}(11,219)=3.0(0.0)\end{array}$ & $\begin{array}{c}\chi(11)^{2}=4.0(0.0) \\
\mathrm{F}(11,219)=44.4(0.0)\end{array}$ & $\begin{array}{c}\mathrm{F}(11,219)=2.11(0.02) \\
\end{array}$ \\
\hline
\end{tabular}

Equation 8 has been re-estimated allowing for varying slopes across-countries. There is considerable variation across Euro-area countries, in the size of the error correction coefficient, of the persistence of inflation and of the response to the unemployment rate. The error correction coefficient is relatively high in Germany, Italy Finland and Greece and low for Austria, Netherlands, France, Ireland and Belgium while for Portugal and Spain it turns out not statistically different from zero. The expected negative sign implies a change in the wage inflation in the opposite direction of any deviation of real wages from productivity observed one year earlier. In the micro-funded Phillips curve of Blanchard and Katz (1999), the speed of adjustment of the EqCM determines the effect of deviations from the perfect competitive wage rule on the NAIRU (Blanchard and Katz (1999), and Cahuc and Zylleberg (2004)). Hence, the effect of supply side distortions on the NAIRU is higher when $\rho$ is high. In terms of equation (3) where $\rho=1-\mu \lambda$, a high coefficient of the error correction term corresponds to a lower persistence of real wages over time,. The opposite holds for countries where $\rho$ is high. With the exception of Spain, the coefficient capturing the nominal rigidity $(\gamma)$ is very precisely estimated and, as expected, less than 1. The inflation persistence is higher in countries where the time persistency 
of real wages is high (Table 4). ${ }^{6}$ Finally, changes in the unemployment rate affect significantly the real wages of all countries but Greece, Ireland and Luxembourg. In the formulation of the Phillips curve with an error correction term, $\beta$, nominal and real wage flexibility can be used interchangeably (see equations (1) and (4)). Hence, $\beta$ determines both the slope of the real wage curve with respect to the unemployment rate and the sacrifice ratio, the change in unemployment required to bring about a fall in the inflation rate. The higher the elasticity, the lower is the sacrifice ratio. The estimated values suggest a relatively low sacrifice ratio in Austria, Portugal, Germany, Belgium and Italy. In contrast, the unemployment cost of disinflation is among the highest in France, Spain, Finland and the Netherlands; for Ireland, Greece and Luxembourg, the wage elasticity with respect to unemployment is not significantly different from zero.

Table 4

Country specific estimates: FGLS for heteroscedastic and contemporaneously correlated residuals

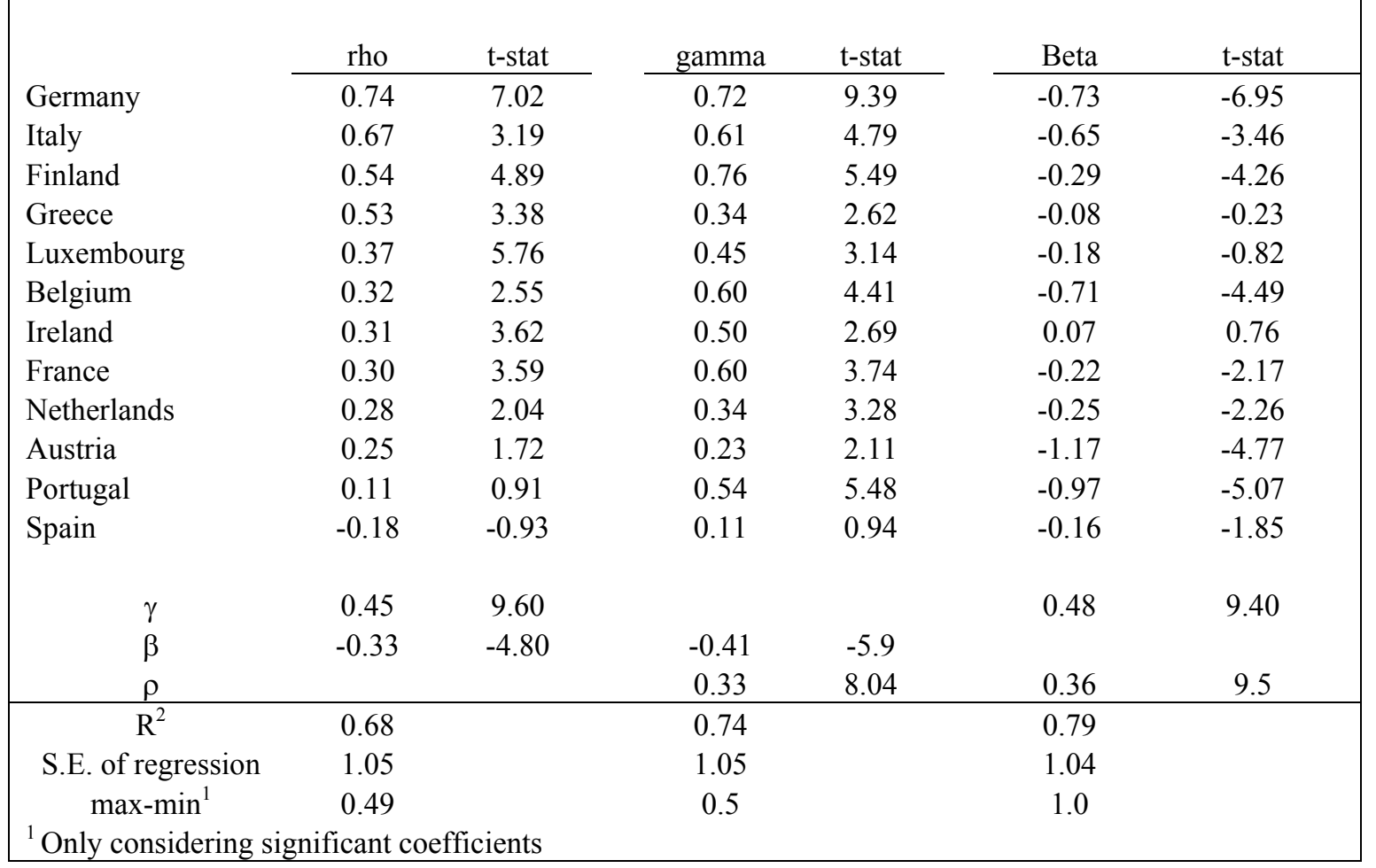

\footnotetext{
${ }^{6}$ The correlation between $\rho$ and $\gamma$ is about 0.70
} 
Graph 7 reports the country-specific combinations of average unemployment and the respective wage flexibility indicators denoted by $\beta, \rho$ and $\gamma$. Across countries, we find a significantly negative correlation between unemployment and the indicator for real wage flexibility $\beta$, while unemployment is apparently unrelated to the degree of nominal inertia $\gamma$. The low correlation between the degree of nominal rigidity and the level of the unemployment rate across countries suggests that nominal factors probably do not play a major role for changes in unemployment over the medium to longer term. Thus, while institutional and structural factors are probably key to an understanding of what determines the mark-up of effective wages over competitive wages over the medium term and, in consequence, the level of equilibrium unemployment, institutional labour market characteristics appear to be of less importance for the degree of nominal inertia in the economy.

\section{Graph 7}

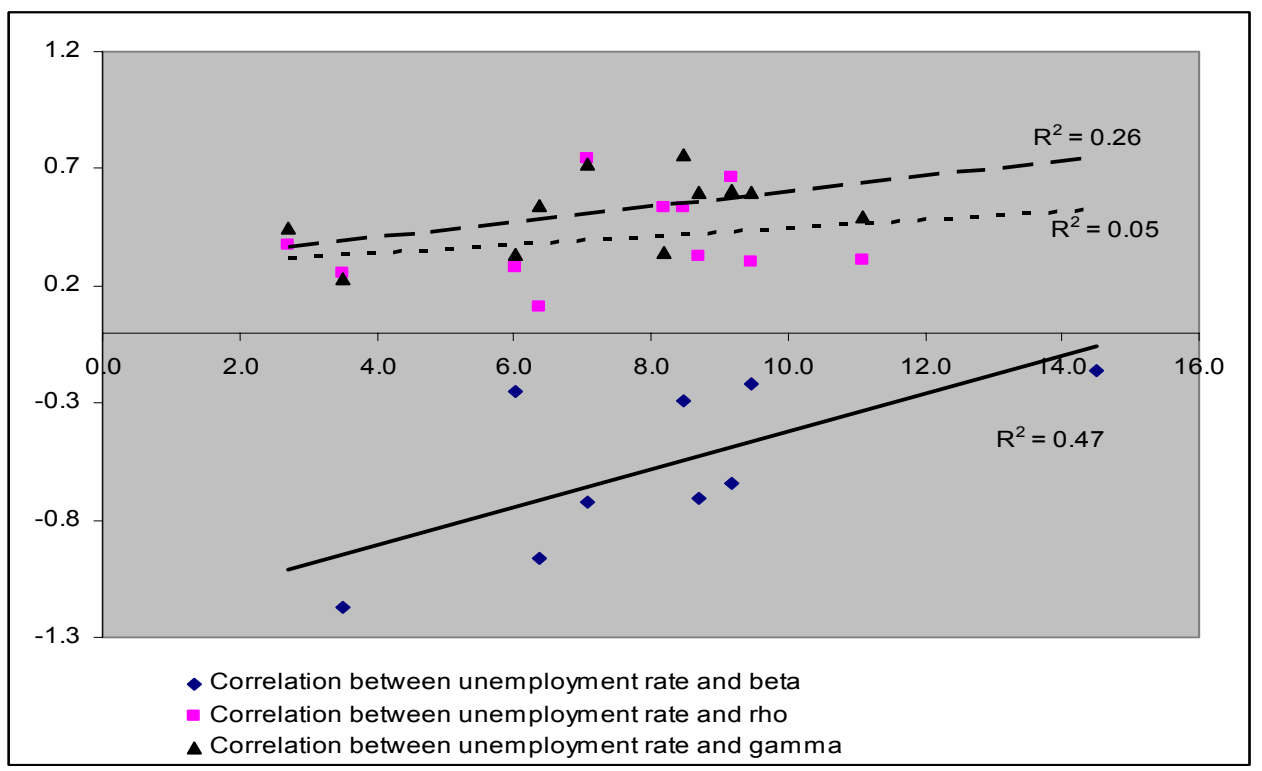

Evidence of a trade-off between adjustment of real wages and of employment quantities is provided by chart 8 , which reports the cross-country scatter plot between the estimated $\beta$ 's and the standard deviation of employment growth over the sample period. The positive relationship suggests that high (low) countries with high elasticity of wages to unemployment have also less (more) volatile employment growth. Moreover the non linearity is suggestive that the trade-off between wage adjustment and employment volatility becomes more "binding" when the response of wage to unemployment is particularly low. 
Graph 8

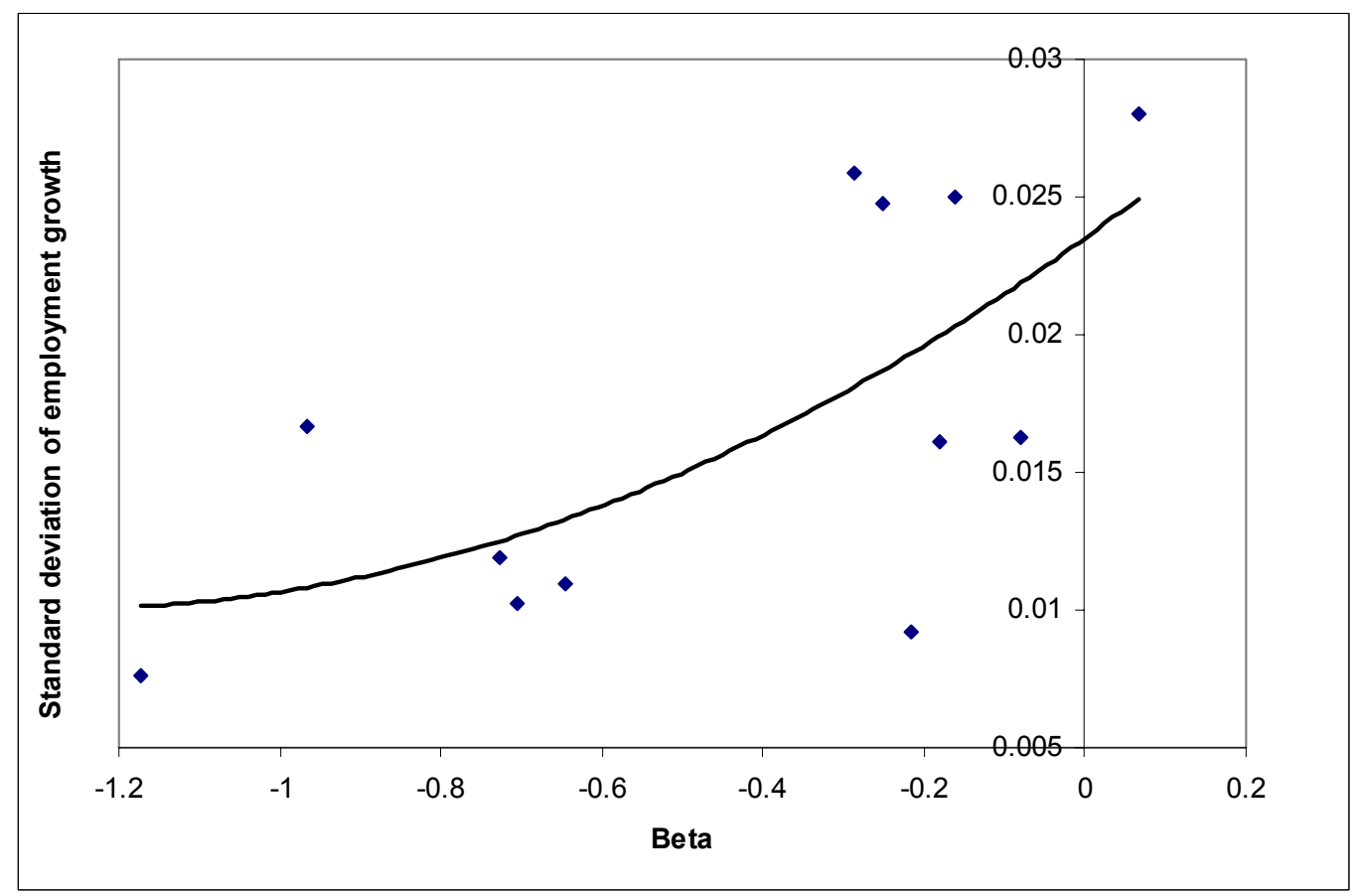

\section{The cyclical responsiveness of relative competitive positions in the euro area}

This section explores how different competitiveness indicators change over the cycle while controlling for the convergence in prices or costs across euro-area countries. The general specification regresses the change in one country's competitiveness vis-à-vis the remaining euroarea countries on the relative output gap and the lagged value of the competitiveness indicator:

$$
\Delta \operatorname{comp}_{i t}=\alpha_{i}+\gamma \operatorname{comp}_{i t-1}+\delta\left(\operatorname{ogap}_{i t}-\operatorname{ogap}_{-i t}\right)+\varepsilon_{i t}
$$

where: $\alpha_{\mathrm{i}}$ is a cross-section fixed effect; comp $_{i t}$ is the (log of the) competitiveness indicator vis-àvis the rest of the euro-area; ogap $_{i t}$ is the output gap of country i at time $t$; ogap ${ }_{-i t}$ is the average output gap of the remaining countries weighted by the bilateral trade weights used in the calculation of the real effective exchange rate; Thus, we distinguish between the change in competitiveness due to cyclical and long-term components. The model is also expressed as an error correction mechanism, implying an equilibrium relationship between each country prices and costs and its main competitors. $\varepsilon_{\mathrm{i}, \mathrm{t}}$ is an error term which should be interpreted as relative to the shock of the reference group of countries. In this way, our formulation captures the effect of transitory asymmetric shocks.

The model estimated is a panel regression based on annual data covering the period 1970-2005 and the 12 euro-area countries. Since this period covers years with different monetary regimes, the parameters of the catching-up term and of the output-gap elasticity may vary over time. In particular, a reduction in transaction costs and more transparent price signals should have made prices and nominal unit labour costs to converge faster even when productivity converges within the EU at a lower rate (i.e. it is the convergence in wages that potentially drives the convergence in unit labour costs). As regards the values of $\delta$, a smoother adjustment to asymmetric shocks requires in a monetary union a more rapid response of relative costs. An increase of real and nominal wage flexibility in all countries reduces the sensitivity of the euro-area output to 
common and country-specific shocks. To the extent that sectoral shocks are more frequent than aggregate shocks in a monetary union, a higher response of sectoral wages is needed. Finally, even given that nominal rigidities within the euro area are not significantly higher than in the US (see, for example, results in Denis et al. 2006), the absence of other adjustment mechanisms places the burden of adjustment mainly on wages. Hence, we should expect positive values for $\delta$ being higher after the introduction of the euro.

The above specification is used to describe the response over the cycle of different price and costs' competitiveness indicators. These indicators represent different stages of the production process and are informative of differences in the cyclical adjustment of relative prices and costs. Table 5 presents the results of the regression analysis based on the real effective exchange rate (REER) with different deflators (panel a) and on various relative prices and costs (panel b). In the euro-area countries there is evidence of convergence in prices and unit labour costs. Whatever the indicator, the impact of its lagged value is always negative and statistically different from zero, suggesting that there is convergence across euro-area members in unit labour costs or prices. The speed of convergence is higher when competitiveness is measured with the real effective exchange rates. This finding depends on the dynamics of the nominal effective exchange rates during the years before the introduction of the euro. In the 1990s, and, especially in the second half, the exchange rate mechanism contributed to stabilise the exchange rate expectations, which made the exchange rate mean reverting. Once equation (10) is tested recursively for the nominal effective exchange rate $^{7}$, the coefficient of the lagged exchange rate is never significantly different from zero before 1990, but it becomes more significant (i.e. the $t$ statistic rises over time) during the 1990s as the EMU was approaching. Moreover, the higher cyclical response of the real effective exchange compared to the relative prices is consistent with the appreciation of the nominal exchange rate during upswings (i.e. the estimated $\delta$ is positive) followed by a reversion toward its mean in the subsequent periods.

Turning to the trade weighted relative price, the convergence in prices and unit labour costs implies that a country with costs and prices higher than the average gains in competitiveness relative to countries with lower relative prices and costs. The convergence is stronger for the export price deflator, which suggests that the arbitrage in the international goods' markets pushes toward price equalisation. In the case of the unit labour costs, a country with unit labour costs $10 \%$ below the average experiences a competitiveness loss around $2 \%$ per year. In the case of unit labour costs, the speed of convergence estimated with the formulation (10) is potentially biased because of missing variables. Unit labour costs are defined as the ratio between wages per employee and output per employee and depend on the developments in these two variables. $\beta$ convergence for wages and productivity implies

$$
\Delta w_{i t}=\alpha_{i}+\beta w_{i t-1}+\gamma \operatorname{ogap} p_{i t}^{*}+\varepsilon_{i t}(10) \text { and } \Delta \pi_{i t}=\lambda_{i}+\alpha \pi_{i t-1}+\delta o g a p_{i t}^{*}+u_{i t}
$$

Consequently, $\beta$-convergence for wages and productivity is equivalent to

$$
\Delta\left(w_{i t}-\pi_{i t}\right)=\alpha_{i}-\lambda_{i}+\beta\left(w_{i t-1}-\pi_{i t-1}\right)+(\beta-\alpha) \pi_{i t-1}+(\gamma-\delta) \operatorname{ogap} p_{i t}^{*}+v_{i t}
$$

where $v_{i t}=\varepsilon_{i t}-u_{i t}$ is white noise if $\varepsilon_{i t}$ and $u_{i t}$ are uncorrelated across countries. Hence, the growth rate of unit labour costs is higher when wages converge faster than productivity (i.e. $\alpha$ $\beta>0$ ). Omitting the additional productivity term will lead to an upward or downward biased estimate of $\gamma$ depending on whether $\alpha>\beta$ or $\alpha<\beta{ }^{8}$. When $\alpha=\beta$, the speed of convergence of ULC is unbiased. Hence to test unbiasedness once should test the restriction $\mathrm{H}_{0}: \alpha=\beta$. To account for

\footnotetext{
${ }^{7}$ Results are available from the authors.

${ }^{8}$ The distortion equals the missing coefficient $(\alpha-\beta) * \eta$ where $-\eta$ is the slope in the least square regression of $\pi$ on $(w-\pi)$.
} 
cross-equation restrictions, equations (10) and (12) have been jointly estimated. This gives $\beta=-$ 2.3 and $\beta-\alpha=-7.2$. A Wald test, used to verify how close the two estimates are, gives a value of the chi-squared statistic of 133, which decisively reject the hypothesis that the estimate of the speed of convergence of unit labour costs is unbiased. However, this unbiased estimate of $\alpha$ is not far from the value found in table $5(-2.4){ }^{9}$

The output gap has a statistically significant positive effect on each competitiveness indicator. An increase in the output gap by 1 percentage point leads to an appreciation of the REER in a range of $0.3 \%$ to $1 \%$, depending on whether the REER is based on the export unit values or unit labour costs. Thus, the estimates yield evidence that the competitiveness channel contributes to reducing cyclical divergences. As expected, abstracting from fluctuations in the nominal bilateral exchange rates, the cyclical response of the trade-weighted costs is lower compared to the REER.

Finally, when the same equation is estimated using wages (not reported for brevity), the elasticity of relative wages to the relative output gap is 0.42 for the total economy and 0.29 for the manufacturing sector. Hence, relative wages react over the cycle less than the relative unit labour costs. This implies that for a country experiencing an increase in the output gap that is larger then the average - i.e. a positive transitory asymmetric shock - productivity grows by less than the average of the remaining euro-area countries; this is more evident in manufacturing than in services. ${ }^{10}$ The opposite holds in the case of a negative transitory asymmetric shock.

Table 5 Changes in the intra-euro competitiveness indicators: pooled estimates

\begin{tabular}{|c|c|c|c|c|c|c|c|c|}
\hline \multirow[t]{3}{*}{ panel a } & \multicolumn{8}{|c|}{ Real effective exchange rate based on } \\
\hline & \multicolumn{2}{|c|}{$\begin{array}{l}\text { ULC total economy } \\
\text { labour costs }\end{array}$} & \multicolumn{2}{|c|}{$\begin{array}{l}\text { Unit labour costs } \\
\text { manufacturing }\end{array}$} & \multicolumn{2}{|c|}{ GDP Deflator } & \multicolumn{2}{|c|}{ Export deflator } \\
\hline & estimate & t-stat & estimate & t-stat & estimate & t-stat & estimate & t-stat \\
\hline $\log (\operatorname{Comp}(-1))$ & -10.7 & $(-6.1)$ & -6.6 & $(-4.3)$ & -9.0 & $(-6.4)$ & -9.2 & $(-4.7)$ \\
\hline Output gap $(-1)$ & 1.1 & $(12.5)$ & 1.2 & $(9.5)$ & 0.8 & $(11.1)$ & 0.3 & $(5.1)$ \\
\hline $\mathrm{R}^{2}$ & 0.38 & & 0.26 & & 0.36 & & 0.14 & \\
\hline s.e. & 1.0 & & 1.0 & & 1.0 & & 1.0 & \\
\hline \multirow[t]{3}{*}{ panel b } & \multicolumn{8}{|c|}{ Trade weighted relative price and costs indices based on } \\
\hline & \multicolumn{2}{|c|}{$\begin{array}{c}\text { Unit labour costs } \\
\text { total economy }\end{array}$} & \multicolumn{2}{|c|}{$\begin{array}{l}\text { Unit labour costs } \\
\text { Manufacturing }\end{array}$} & \multicolumn{2}{|c|}{ GDP Deflator } & \multicolumn{2}{|c|}{ Export deflator } \\
\hline & Estimate & t-stat & estimate & t-stat & estimate & t-stat & estimate & t-stat \\
\hline $\log (\operatorname{Comp}(-1))$ & -2.4 & $(-5.4)$ & -2.2 & $(-3.1)$ & -1.9 & $(-4.3)$ & -3.2 & $(-4.9)$ \\
\hline Output gap $(-1)$ & 0.7 & $(16.1)$ & 0.8 & $(10.3)$ & 0.4 & $(8.5)$ & -0.2 & $(-3.2)$ \\
\hline $\mathrm{R}^{2}$ & 0.65 & & 0.42 & & 0.60 & & 0.34 & \\
\hline s.e. & 1.0 & & 1.0 & & 1.0 & & 1.01 & \\
\hline
\end{tabular}

Note: Dependent variable is $100 * \Delta \log (\operatorname{comp})$. Cross-section fixed effect included; Estimates corrected for contemporaneous correlation and heteroschedastic residuals. All variables are normalised with respect to the weighted average of remaining euro-area countries with bilateral trade weights. Unit wage costs are in the manufacturing sector. Sample period: $1970-2005$

The equation was estimated over a period (1970-2005) characterised by a series of nominal and real shocks as well as by changes in the monetary regime. It is therefore of interest to verify whether the foregoing estimates are stable over time. Stability has been evaluated by reestimating recursively the coefficients of the model starting from the 1970-1979 period and

\footnotetext{
${ }^{9}$ These estimates control for heteroskedasticity and contemporaneous correlation of the error term (i.e. we estimate the system (with SURE). When we estimate controlling for the productivity with cross equation restrictions, we get $\gamma-\delta=0.7$ and $\gamma=0.39$.

10 It should be stressed that this response of relative productivity does not mean that productivity is anti-cyclical. It only means that productivity rises by less than in the remaining countries. However, the results of the pooled estimation conceal countryspecific responses to asymmetric shocks. Joint estimation of equations (10) and (12) gives $\gamma=0.4$ and $\gamma-\delta=0.7$.
} 
adding observations each time on a five years interval. Thus, it is possible to identify whether and when breaks occurred in the relationship linking changes in competitiveness with the catching-up term and the output-gap. The coefficients are plotted over time for the equations of the unit labour costs for the total economy and the manufacturing sector (Graph 9).

The coefficient of the lagged unit labour costs is not invariant over time. In the case of the total economy, in the 1970s and the first half of 1980s, the forces that pushed unit labour costs to diverge prevailed over those that promoted convergence. It is only since the second half of the 1990s that national unit labour costs tend to share a common trend. ${ }^{11}$ The response of unit labour costs over the cycle is relatively more stable, slightly higher in the 1970s than in more recent years. As expected, monetary union spurred convergence in unit labour costs. This convergence in unit labour costs appears to be driven by the wage component, which may harm overall competitiveness as long as the levels of productivity do not converge. In contrast, after 1998, there is no statistically significant change in the response of unit labour costs to asymmetric shocks.

Graph 9: Stability over time of the catching-up and output-gap coefficients: recursive estimates

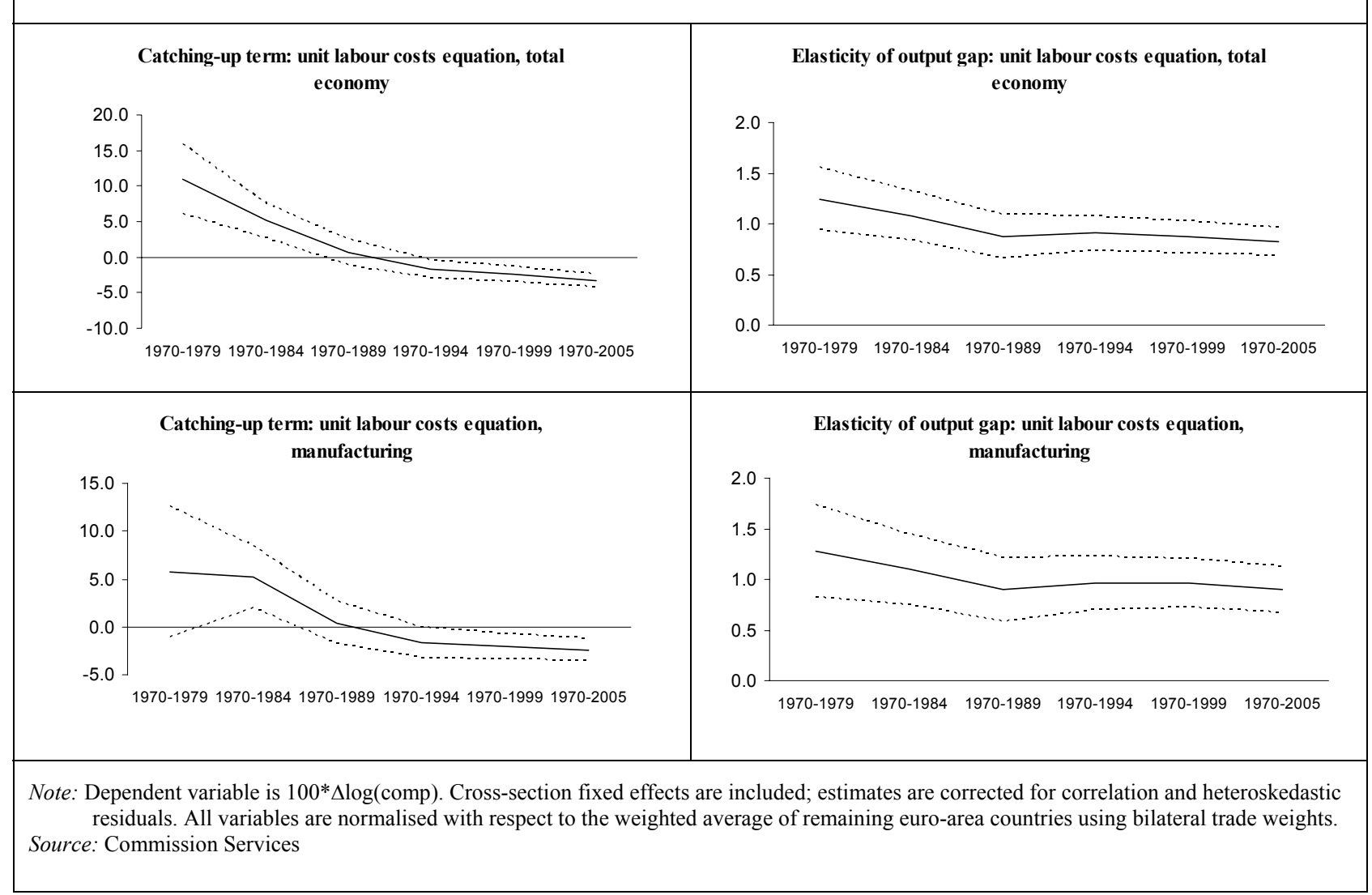

Asymmetric responses of unit labour costs to positive and negative asymmetric shocks can delay the change in competitiveness required by the cyclical conditions, and can eventually give rise to periods of over-cooling or over- heating. ${ }^{12}$ This asymmetry may generate persistent cross-country

11 In the case of the manufacturing sector, the catching up coefficient follows the same pattern as for the total economy and has a final estimate that is within the uncertainty of the estimate obtained for the total economy. Thus, it cannot be excluded that in the second half of the $1990 \mathrm{~s}$ nominal unit labour costs of the manufacturing sector converged at the same rate as nominal unit labour costs for the whole economy.

12 These effects can arise from downward wage stickiness (e.g. Taylor, 1980) or menu costs (e.g. Ball and Mankiw, 1994). Asymmetric responses in unit labour costs may result from output and employment asymmetries as in the sectoral-shifts model of Lillien (1982) or because hiring new workers is less costly than firing existing ones. 
differences in GDP growth rates. To detect the presence of asymmetric responses in the labour costs, table 2 shows the outcome for the estimates over the period 1980-2005, distinguishing separately the effect of positive and negative output gaps.

The results suggest that, while the speed of convergence is not affected by the cyclical conditions, the growth in unit labour costs is more reactive over the cycle when the economy is running above rather than below potential. When the total economy is hit by a positive transitory shock bringing GDP above trend by 1 percentage point, the growth rate of relative unit labour costs rises by 1 percentage point. In contrast, when the shocks fade away, the growth of relative unit labour costs falls by about 0.7 of a percentage point. This difference implies either that only $70 \%$ of the increase in the relative unit labour cost growth is reabsorbed within a year or that much more slack of the economy is needed to moderate such growth. As far as the manufacturing sector is concerned, the estimates provide less support for the hypothesis of asymmetric behaviour in the unit labour costs.

Table 6: Asymmetries in the changes of unit labour costs growth - pooled estimates

\begin{tabular}{|c|c|c|c|c|c|c|c|c|}
\hline & \multicolumn{4}{|c|}{ Total Economy } & \multicolumn{4}{|c|}{ Manufacturing } \\
\hline & \multicolumn{2}{|c|}{ Positive output gap } & \multicolumn{2}{|c|}{ Negative output gap } & \multicolumn{2}{|c|}{ Positive output gap } & \multicolumn{2}{|c|}{ Negative output gap } \\
\hline & estimate & t-stat & estimate & t-stat & estimate & t-stat & estimate & t-stat \\
\hline $\log$ & -7.35 & $(-16.2)$ & -7.51 & $(-14.4)$ & -6.35 & $(-9.6)$ & -6.55 & $(-10.5)$ \\
\hline $\begin{array}{l}\text { ULCComp (- } \\
\text { 1) }\end{array}$ & & & & & & & & \\
\hline Output gap(-1) & 1.02 & $(16.1)$ & 0.70 & $(13.6)$ & 0.85 & $(8.7)$ & 0.75 & $(7.8)$ \\
\hline R squared & 0.82 & & 0.77 & & 0.65 & & 0.65 & \\
\hline Standard error & 1.02 & & 1.02 & & 1.02 & & 1.02 & \\
\hline
\end{tabular}

Note: Dependent variable is $100 * \Delta \log (\mathrm{comp})$. Cross-section fixed effects are included; estimates are corrected for contemporaneous correlation and heteroskedastic residuals. All variables are normalised with respect to the weighted average of remaining euro-area countries using bilateral trade weights. Sample period: 1980-2005.

Source: Commission Services

Finally, to detect country-specific responses of unit labour costs over the cycle, the model was reestimated allowing for the coefficient of the output gap to vary across countries. Country-specific parameters are reported in the column (1) of table 7, while columns (3) and (5) show the outputgap elasticity when the economy is running, respectively, above and below potential (columns positive and negative output gap). Columns (2), (6), and (9) report the rank of the coefficients in the list of countries.

The results suggest that there is much more heterogeneity across countries in the cyclical behaviour of unit labour costs growth when GDP is below than when it is above potential. When no distinction is made for the state of GDP relative to potential, the difference between the largest and the lowest response (respectively, Italy and Portugal) is 0.8 ; this gap reaches 1.3 when the output gap is positive and 2.1 when it is negative. Also, the distribution across countries of the output-gap elasticity changes with the position of the cycle. When GDP is running above potential, the countries at the extremes of the distribution are Italy and France, respectively. In contrast, when GDP is below potential, the lowest response is estimated for Portugal (with an estimated elasticity statistically insignificantly different from zero) and the highest for Austria.

The evidence of a difference in the extent of cross-countries heterogeneity in periods of positive and negative output-gap is formally confirmed by poolability tests. In the equation with no 
positive and negative output gaps (columns (4) and (7)). Without any cyclical restrictions, the response of relative wages is statistically significant for few countries only (namely Germany, Spain, Ireland, Italy and Finland). In contrast, when GDP is running above potential, the elasticity of relative wages to the relative output gap is highest for Italy, the Netherlands, Spain and Germany and lowest for Austria, France and Greece. Similarly, the response is the highest when GDP is below potential in Germany, Spain, Ireland and Finland, while in the remaining countries wage rigidity prevails. This implies that in response to positive asymmetric shocks, nominal wages in one country grow more than in the other euro-area countries, but do not adjust downward when GDP falls below potential with harmful consequences for overall competitiveness.

Table 8: Country-specific output-gap elasticity of wage growth - total economy

\begin{tabular}{|c|c|c|c|c|c|c|c|c|c|}
\hline & $(1)$ & $(2)$ & (3) & $(4)$ & $(5)$ & $(6)$ & $(7)$ & $(8)$ & $(9)$ \\
\hline & estimate & t-stat & rank & estimate & t-stat & rank & estimate & t-stat & rank \\
\hline $\begin{array}{l}\text { Log wages } \\
(-1)\end{array}$ & -2.6 & $(6.0)$ & & -2.5 & $(-6.5)$ & & -2.49 & $(-5.3)$ & \\
\hline & $\begin{array}{l}\text { Output } \\
\text { gap (-1) }\end{array}$ & & & $\begin{array}{c}\text { Output gap } \\
(-1)>0\end{array}$ & & & $\begin{array}{c}\text { Output gap } \\
(-1)<0\end{array}$ & & \\
\hline Germany & 0.86 & $(4.3)$ & 1 & 1.15 & (4.1) & 4 & 1.38 & 3.9 & 1 \\
\hline Spain & 0.64 & (4.3) & 2 & 1.21 & (5.2) & 3 & 1.02 & 3.6 & 2 \\
\hline Ireland & 0.54 & (4.2) & 3 & 0.77 & (3.7) & 8 & 0.71 & 2.7 & 3 \\
\hline Italy & 0.49 & (1.8) & 4 & 1.98 & $(5.0)$ & 1 & -0.13 & -0.3 & 8 \\
\hline Finland & 0.42 & (4.5) & 5 & 0.85 & (4.6) & 7 & 0.59 & 4.2 & 4 \\
\hline Netherlands & 0.32 & (1.2) & 6 & 1.37 & (3.9) & 2 & -0.09 & -0.2 & 7 \\
\hline Portugal & 0.32 & (1.5) & 7 & 1.03 & (4.7) & 5 & -0.68 & -1.7 & 10 \\
\hline BLEU & 0.26 & (1.1) & 8 & 0.88 & (2.7) & 6 & -0.17 & -0.4 & 9 \\
\hline France & 0.18 & $(0.7)$ & 9 & 0.08 & $(0.2)$ & 10 & -0.01 & 0.0 & 6 \\
\hline Austria & -0.13 & $(-0.6)$ & 10 & -0.30 & $(-1.0)$ & 11 & 0.21 & 0.4 & 5 \\
\hline Greece & -0.22 & $(-0.4)$ & 11 & 0.28 & $(0.4)$ & 9 & -0.72 & -0.9 & 11 \\
\hline Average & 0.3 & & & 0.85 & & & 0.2 & & \\
\hline R-squared & 0.55 & & & 0.66 & & & 0.53 & & \\
\hline Std. error & 1.00 & & & 1.00 & & & 1.00 & & \\
\hline Poolability & $\mathrm{F}_{(10,363)}=$ & & & $\mathrm{F}_{(10,363)}=$ & & & $\mathrm{F}_{(10,363)}=$ & & \\
\hline & 1.32 & & & 0.68 & & & $1.96^{*}$ & & \\
\hline p-value & 0.22 & & & 0.74 & & & 0.04 & & \\
\hline
\end{tabular}

Note: Dependent variable is $100 * \Delta \log ($ comp). Cross-section fixed effects are included; estimates are corrected for contemporaneous correlation and heteroskedastic residuals. All variables are normalised with respect to the weighted average of remaining euro-area countries using bilateral trade weights. Countries are ranked in decreasing order of the effect of the output gap on growth of unit labour costs. The poolability test is a Chow test applied to disturbances that have been transformed into spherical disturbances.

Source: Commission Services .

Turning to the manufacturing sector, because of the discipline imposed by the international goods markets, one should expect unit labour costs to be less asymmetric over the cycle in this sector. This prediction is only partially confirmed by the data (Table 9). Portugal and Greece still rank among the countries with more asymmetric behaviour of labour costs over the cycle. Compared with the results for the total economy, the degree of asymmetry for manufacturing is less accentuated in Italy and Finland and more important for the Netherlands and Spain. It is also worth mentioning that, when GDP is running above potential, unit labour costs are more volatile in manufacturing than in the total economy, with the exception of Austria and Portugal. When the 
GDP is below potential, a stronger response is estimated in the case of France, Italy and, to a lesser extent, Austria and Finland. Finally, the hypothesis that the elasticity of unit labour costs in manufacturing is the same across countries is rejected when no allowance is made for positive and negative output gaps. However, it is not possible to reject the poolability hypothesis for the equations that distinguish the elasticity according to whether GDP is running above or below potential. The evidence that in periods of negative output gaps, there is a significant degree of heterogeneity across countries in the elasticity of unit labour costs for the total economy but homogeneity for the manufacturing sector suggests that the main sources of the asymmetric adjustment in ULC derive from the service sector.

Table 9: Country-specific output-gap elasticity of unit labour costs - manufacturing

\begin{tabular}{|c|c|c|c|c|c|c|c|c|c|}
\hline & (1) & (2) & (3) & (4) & (5) & (6) & (7) & (8) & (9) \\
\hline & estimate & t-stat & rank & estimate & t-stat & rank & estimate & t-stat & rank \\
\hline \multirow[t]{2}{*}{$\log$ UWC(-1) } & -1.96 & $(-3.6)$ & & -1.77 & $(-2.9)$ & & -1.93 & $(-3.2)$ & \\
\hline & $\begin{array}{c}\text { Output gap } \\
(-1)\end{array}$ & & & $\begin{array}{c}\text { Output gap } \\
(-1)>0\end{array}$ & & & $\begin{array}{c}\text { Output } \\
\operatorname{gap}(-1)<0\end{array}$ & & \\
\hline Italy & 1.82 & $(8.0)$ & 1 & 2.66 & $(6.0)$ & 1 & 2.32 & $(4.9)$ & 1 \\
\hline France & 1.31 & $(5.8)$ & 2 & 1.81 & (4.4) & 3 & 1.60 & (3.1) & 3 \\
\hline Netherlands & 1.23 & $(4.8)$ & 3 & 1.97 & (3.6) & 2 & 1.06 & $(2.0)$ & 8 \\
\hline Spain & 1.15 & (6.1) & 4 & 1.64 & $(4.5)$ & 4 & 1.24 & (3.2) & 5 \\
\hline Germany & 1.07 & (6.3) & 5 & 0.98 & (3.3) & 9 & 1.15 & (3.0) & 6 \\
\hline Austria & 1.05 & $(2.8)$ & 6 & 1.16 & $(2.1)$ & 7 & 1.94 & $(2.3)$ & 2 \\
\hline Finland & 1.01 & (6.1) & 7 & 1.49 & (3.8) & 6 & 1.43 & (6.1) & 4 \\
\hline Greece & 0.63 & $(0.9)$ & 8 & 1.54 & (1.4) & 5 & 1.11 & $(0.9)$ & 7 \\
\hline Portugal & 0.56 & $(2.0)$ & 9 & 1.09 & $(3.0)$ & 8 & 0.06 & $(0.1)$ & 11 \\
\hline BLEU & 0.10 & $(0.3)$ & 10 & -0.13 & $(-0.3)$ & 10 & 0.71 & (1.5) & 9 \\
\hline Ireland & -0.05 & $(-0.1)$ & 11 & -0.44 & $(-0.8)$ & 11 & 0.29 & 0.4 & 10 \\
\hline $\mathrm{R}$ squared & 0.54 & & & 0.48 & & & 0.46 & & \\
\hline Std. error & 1.00 & & & 1.00 & & & 1.00 & & \\
\hline Average & 0.9 & & & 1.3 & & & 1.2 & & \\
\hline Max-Min & 1.9 & & & 3.1 & & & 2.3 & & \\
\hline $\begin{array}{l}\text { Poolability } \\
\text { test }\end{array}$ & $\mathrm{F}_{(10,363)}=$ & & & $\begin{array}{c}\mathrm{F}_{(10,363)} \\
1.33\end{array}$ & & & $\begin{array}{c}\mathrm{F}_{(10,363)}= \\
0.67\end{array}$ & & \\
\hline p-value & 0.038 & & & 0.21 & & & 0.75 & & \\
\hline
\end{tabular}

Note: Dependent variable is $100 * \Delta \log (\mathrm{comp})$. Cross-section fixed effects are included; estimates are corrected for contemporaneous correlation and heteroskedastic residuals. All variables are normalised with respect to the weighted average of remaining euro-area countries using bilateral trade weights. Countries are ranked in decreasing order of the effect of the output gap on the growth of unit labour costs.

Source: Commission Services

A significant difference between the output gap elasticity for different cyclical phases may delay the adjustment of relative unit labour costs and be a cause of diverging output-growth rates. It turns out that for the total economy this difference is highest for Portugal, Italy, Greece, and Finland and lowest for Austria and Germany. Graph 10 suggests that this rigidity in the adjustment led to divergent growth rates of relative unit labour costs in the early years of monetary union. This graph reports on the horizontal axis the difference of the output gap elasticity when GDP is above potential from the value estimated when it is below, while the vertical axis displays the average change in the unit labour costs relative to the EU average for the post-1998 years. The asymmetry in the cyclical behaviour of unit labour costs in countries, 
such as Italy and Portugal, implies a higher sacrifice ratio, i.e. the increase in unemployment needed to trigger a change in competitiveness.

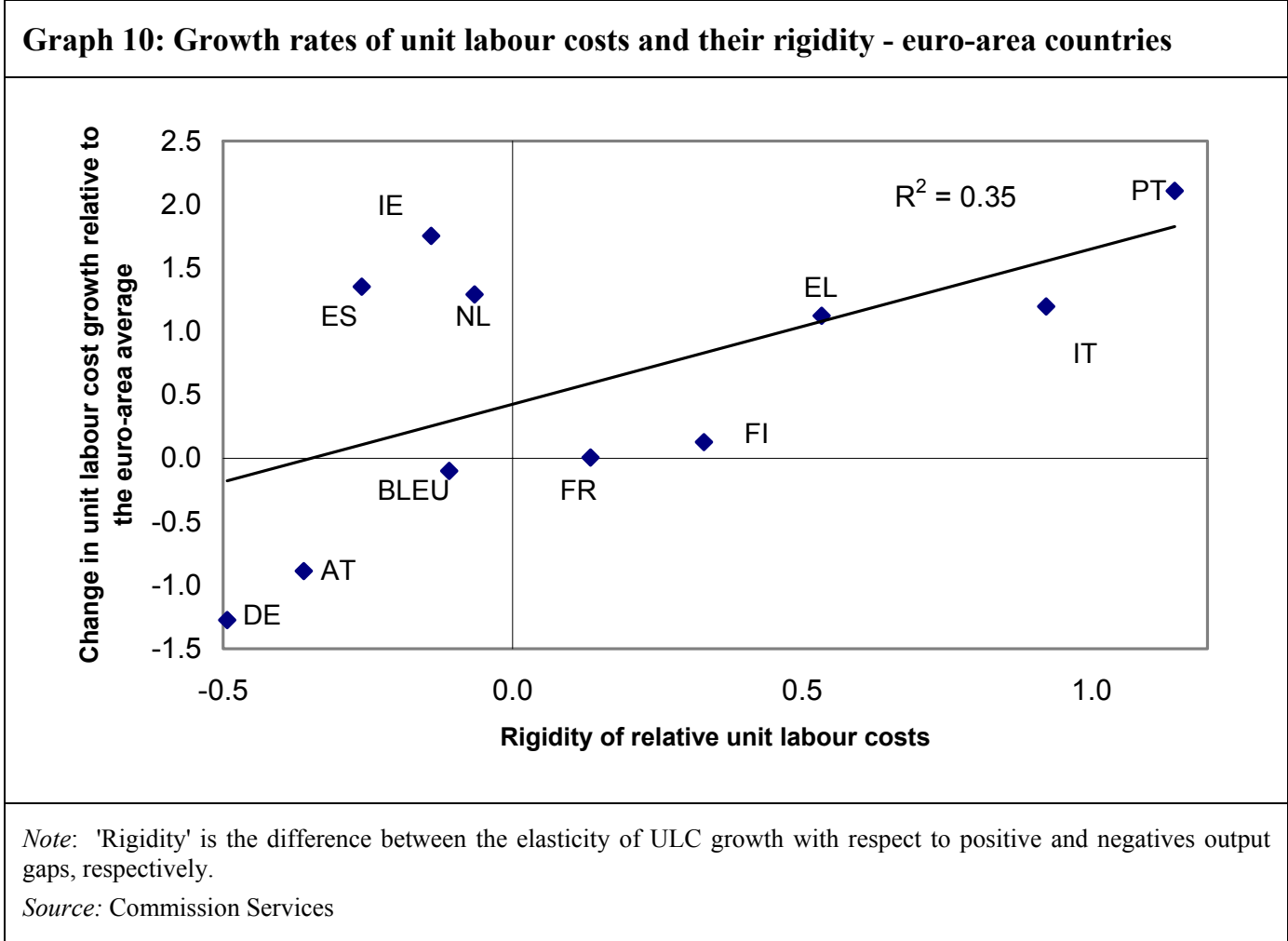




\section{Concluding remarks}

Both common macroeconomic shocks and country-specific developments have subjected the flexibility of wage setting mechanisms in the euro area to a stress test in recent years. Against this background, the paper has taken a fresh look at wage flexibility in EMU attempting to draw a few lessons from the experience of the early years. After providing a brief description of the stylised facts regarding nominal and real wage and unit labour cost developments in the euro area over the recent business cycle, we presented an empirical assessment of wage inertia based on new econometric estimates of a Phillipscurve type wage equation across euro area countries. Our findings suggest the existence of a significant degree of nominal wage rigidity in the euro area economy. The coefficient that captures the inflation persistence between 0.4 and 0.5 implies that about $50 \%$ of the inflation of the previous year is passed on into current wage growth. This value suggests a considerable effect of the inflationary climate on current developments of wage inflation. The coefficient of the (log-) wage share is consistent with a BlanchardKatz error correction term. If real wages are higher than productivity, or similarly if the mark up falls, there is a correction in the following year in the growth rate of nominal wages that keeps real wages tied with productivity. According to our estimate only $40 \%$ of the deviation is closed in one year, which also implies that through the error correction mechanism further persistence is added to the wage growth process. Wages do react to labour market conditions, though; in the case of our preferred specification, an increase in unemployment by 1 percentage point leads to a downward wage adjustment of about $0.3 \%$.

Wage formation processes differ significantly across the euro area. Formal econometric tests are indicative of considerable variation across euro-area countries, in the size of the error correction coefficient, of the persistence of inflation and of the response to the unemployment rate. Obviously, these differences also impact upon the cyclical responsiveness of relative competitive positions among euro area countries, and our estimates indeed point to a significant degree of cross-country heterogeneity. Moreover, we find evidence that the adjustment reaction is not symmetric over the cycle. When GDP is running above potential, the elasticity of relative wages to the relative output gap is highest for Italy, the Netherlands, Spain and Germany and lowest for Austria, France and Greece; on the other hand, when GDP is below potential the response is the highest in Germany, Spain, Ireland and Finland, while in the remaining countries wage rigidity prevails.

We conclude that from a bird's eye perspective euro area wage and labour cost dynamics have been quite benign in the past couple of years. However, our estimates suggest that persistent cross-country differences in wage and labour cost developments have not always reflected warranted adjustment needs; they are rather indicative of an eventually insufficient degree of wage flexibility in the euro area. 


\section{References}

AIZEMAN, J. and J. FRENKEL (1986), "Sectoral wages and the real exchange rate", NBER Working Paper No 1801.

ALLSOPP, C. and D. VINES (1998), "The assessment: Macroeconomic policy after EMU", Oxford Review of Economic Policy, 14, No. 3, 1-23.

ALTISSIMO, F., P. BENIGNO and D. RODRIGUEZ-PALENZUELA (2004), "Inflation Differentials in a Currency Area: Facts explanations and policy", Mimeo.

ANDERSEN, T.M. (2003), "Wage formation and European integration", mimeo, European Commission DG ECFIN.

ANDERSEN, T.M. (2004), "Heterogeneous wage formation under common monetary policy", CEPR, Discussion Paper No 4430.

Ball, L. and Mankiw, G. "Asymmetric Price Adjustment and Economic Fluctuations", Economic Journal, 104, Mar. 1994, 247-261.

BALTAGI, B.H. (2002), "Econometric Analysis of Panel Data" , John Wiley and Sons.

BALTAGI, B.H. and Li, Qi (1995), "Testing AR(1) against MA(1) disturbances in an error component model", Journal of Econometrics, 68, 133-51.

BATINI, N., B. JACKSON, and S. NICKELL (2002), "Inflation Dynamics and the labour Share in the U.K", External MPC Unit Discussion Paper No. 2, Bank of England.

BECK,N. and J. KATZ, "What to Do ( and Not to Do) with Time-Series-Cross-Section Data in Comparative Politics", American Political Science Review, 89, 1995, 634-647.

BEISSINGER, T. and C. KNOPPIK (2003), "Sind Nominallöhne starr? Neuere Evidenz und wirtschaftspolitische Implikationen", IZA Discussion Paper No. 800, June 2003.

BLANCHARD, O (1997), "The Medium run", Brookings Papers on Economic Activity, 2, 89-158.

BLANCHARD, O (1998), " Revisiting European unemployment: Unemployment, capital accumulation, and factor prices" Geary Lecture, ESRI June 1998.

BLANCHARD, O (2006), "European unemployment the evolution of facts and ideas", Economic Policy,21 No. 45.

BLANCHARD, O. and L. F. KATZ (1999), "Wage Dynamics : Reconciling Theory and Evidence", American Economic Review,89, 69-74.

CAHUC, P. and A. ZYLBERBERG (2004), "Labor Economics", MIT Press.

BOOTH , A. (1995), "The economics of the Trade Union", Cambridge University Press.

COENEN, G. (2003), "Downward nominal wage rigidity and the long-run Phillips curve: Simulation-based evidence for the euro area", Background study related to the ECB's definition of price stability, ECB, http://www.ecb.int/pub strategy/CoenenWageRigidity.pdf;

DECRESSIN, A. and J. DECRESSIN (2002), "On sand and the role of grease in labor markets: How does Germany compare?" IMF Working Paper NO 02/164.

DESSY, O. (2002), "Nominal wage rigidity in the European countries: Evidence from the Europanel", $\quad$ CREST-INSEE,http://www.diw.de/deutsch/abteilungen/ldm/archiv/ ar2002/panel2002/session_d2/111_dessy.pdf.

DORNBUSCH, R (1974), "Tariffs and non-traded goods", Journal of International Economics, 4, 177-196. 
DUFRESNE, A. and E. MERMET (2002), "Trends in the coordination of collective bargaining in Europe", http://www.etuc.org/ETUI/Publications/DWP/ 02mermet.pdf.

EUROPEAN COMISSION (1997), "Economic Policy in EMU, Part B: Specific topics", DG ECFIN Economic papers No. 125.

EUROPEAN COMISSION (2001), "The EU economy: 2001 review", European Economy No. 73.

EUROPEAN COMISSION (2002), "The EU economy: 2002 review", European Economy No. 6/2002.

GALI, J. and M. GERTLER (1999), "Inflation Dynamics: A Structural Econometrics Analysis," Journal of Monetary Economics,44, 195-222.

GALI, J., M. GERTLER, and D. LÓPEZ-SALIDO (2001) "European inflation dynamics", European Economic Review, 45, 1237-70.

GALI, J., M. GERTLER, and D. LÓPEZ-SALIDO (2002), "Mark-ups, gaps and the welfare costs of business fluctuations", mimeo, Universita Pompeu Fabra http://www.econ.upf.es/ gali/pdf_files/gglgap.pdf .

GORDON, R. J. (1990), “US Inflation, Labor's Share and the Natural Rate of Unemployment", In: Economics of Wage Determination, edited by H. Koenig. Berlin and New York: Springer Verlag, 1-34.

GROTH C. and A. JOHANSSON (2002) "Bargaining structure and nominal wage flexibility", Stockholm University, Institute for Economic Studies Seminar Paper No. 709.

HANCKÉ, B. and D. SOSKICE (2003), "Wage-setting and inflation targets in EMU", Oxford Review of Economic Policy, 19, No. 1, 149-160.

HOLDEN, S. (2002), "The costs of price stability - downward nominal wage rigidity in Europe", mimeo, University of Oslo.

IMF (2003), "Euro area Policies: selected issues", IMF Country Report No. 3/298, Washington D.C.

KIELER, M. (2003), “The ECB's inflation objective” IMF Working Paper 03/91.

KNOPPIK, C. and T. BEISSINGER (2001), "How rigid are nominal wages? Evidence and implications for Germany", IZA Discussion Paper No. 357.

LILIEN, D.M. (1982), "Sectoral Shifts and Cyclical Unemployments", Journal of Political Economy, 90(4), 777-93.

MANZINI P. and D. SNOWER (2002), "Wage determination and the sources of bargaining power", IZA Discussion Paper No. 535, July.

MARSHALL, R.C. and A. MERLO (1999): Pattern Bargaining”, Penn Institute for Economic Research, PIER Working paper 01-032.

MuRPHY, K.J. (2000), "What effect does uncertainty have on the length of labour contracts?", Labour Econmics, Vol. 7,181-200.

PESARAN, M. H. and SMITH, R. (1995), "Estimating long-run relationship from dynamic heterogeneous panel”, Journal of Econometrics, 68, 79-113.

PISSARIDES, C.A. (1997), "The need for labor-market flexibility in a European economic and monetary union", Swedish Economic Policy Review, Vol. 4 (2), 513-546. 
PISSARIDES, C.A. (1998), "The Impact of Unemployment Cuts on Employment and Wages: The Role of Unemployment Benefits and Tax Structure", European Economic Review, 42, 155-84.

CHEN, P. CHIARELLA, C. and SEMMLER, W. "Keynesian Dynamics and the WagePrice Spiral. Analyzing and Estimating a Baseline Disequilibrium Model" forthcoming Journal of Monetary Economics.

GREENE, W (2003), "Econometric Analysis" fifth edition Prentice Hall.

SHAFIR, E.P., Diamond, P. and A. Tversky (1997), "Money illusion", Quarterly Journal of Economics, Vol. 112, pp. 341-374.

UK HM Treasury (2003): "EMU and labour market flexibility", EMU study.

TAYLOR, J. (1980), "Aggregate Dynamics and Staggered Contracts", Journal of Political Economy, 88, 1-24.

Turner, D. and E. SEGHEZZA (1999), "Testing for a common OECD Phillips curve", OECD Economics Department Working Paper No 219.

Whelan, K (2002), "Real wage dynamics and the Phillips curve", Finance and Economic Discussion Series No 2, Federal Reserve Board.

VAN HET KAAR, R. and M. GRÜNELL (2001), "Variable pay in Europe" EIROnline, April 2001, http://www.eiro.eurofound.ie/2001/04/study/TN0104201S.html. 